\title{
Devonian-Permian sedimentary basins and paleogeography of the Eastern Russian Arctic: An overview
}

\author{
Victoria B. Ershova ${ }^{\mathrm{a}, *}$, Andrei V. Prokopiev ${ }^{\mathrm{b}}$, Andrey K. Khudoley ${ }^{\mathrm{a}}$ \\ a Institute of Earth Sciences, St. Petersburg State University, Universitetskaya nab. 7/9, St. Petersburg 199034, Russia \\ b Diamond and Precious Metal Geology Institute, Siberian Branch, Russian Academy of Sciences, Lenin Pr. 39, Yakutsk 677980, Russia
}

\section{A R T I C L E I N F O}

\section{Article history:}

Received 13 July 2015

Received in revised form 9 March 2016

Accepted 20 March 2016

Available online 26 March 2016

\section{Keywords:}

Arctic

Russia

Paleogeography

Paleozoic

Provenance

\begin{abstract}
A B S T R A C T
The Arctic basins attract broad international interest because of the region's potentially significant undiscovered hydrocarbon resources. The Russian High Arctic is mostly represented by broad shelves, with a few wells drilled only in its western part (Kara and Barents shelves). This contribution provides an overview of the geological setting, stratigraphy, paleogeography, and tectono-sedimentary evolution of the middle-late Paleozoic basins of the Eastern Russian Arctic, including: Severnaya Zemlya, the New Siberian Islands, northern Siberia, the Taimyr and Chukotka peninsulas, and Wrangel Island. Reconstructing the geological evolution of the Eastern Russian Arctic during the middle-late Paleozoic is very difficult because the region was overprinted by a number of late Paleozoic to early Mesozoic tectonic events.
\end{abstract}

(c) 2016 Elsevier B.V. All rights reserved.

\section{Introduction}

The Arctic basins have attracted an increasing amount of international interest in recent years because of the potential for containing a significant proportion of the world's undiscovered hydrocarbon (principally gas) resources. The Russian High Arctic is mostly represented by broad shelves, with a few wells drilled in the Barents and Kara seas penetrating Mesozoic strata. No deep wells have been drilled in the Eastern Russian Arctic shelves within the Laptev, east Siberian and Chukchi seas. Despite the importance of the middle-late Paleozoic sedimentary basins of the Russian High Arctic, the study of Paleozoic strata in this region has been limited to the remote archipelagoes and coastal areas of the adjacent mainland, which offer snapshots into their Paleozoic history. This paper provides an overview of the Devonian-Permian stratigraphy, depositional environments and available provenance studies across Severnaya Zemlya, the New Siberian Islands, northern Siberia, the Taimyr and Chukotka peninsulas, and Wrangel Island (Fig. 1). Our overview is based on all available published data, the majority of which was acquired during geological mapping in the 1960s, 1970s and 1980s. The level of detail varies significantly among these geological investigations across different parts of the study area, due to remote locations and brief periods of time for field work. The compilation of a correlative stratigraphic framework also is complicated by the overprinting of younger tectonic and magmatic events, and associated metamorphism. Here,

\footnotetext{
* Corresponding author.

E-mail address: v.ershova@spbu.ru (V.B. Ershova).
}

we also analyze the available detrital zircon data from the Eastern Russian Arctic.

\subsection{Severnaya Zemlya}

\subsubsection{Stratigraphy}

The Severnaya Zemlya Archipelago comprises four big islands (Pioneer, October Revolution, Komsomolets and Bol'shevik), along with several smaller islets and island groups. Pioneer, October Revolution and Komsomolets islands are mainly composed of Cambrian to Upper Devonian deposits, while Cambrian-Ordovician rocks with a few exposures of Upper Carboniferous-Permian and Mesozoic deposits crop out on Bol'shevik Island (Makariev, 2013).

1.1.1.1. Devonian. Lower Devonian strata exposed on Pioneer, October Revolution and Komsomolets islands are very similar in composition and sedimentary facies, and overlie Upper Silurian rocks with an erosional unconformity (Fig. 2). The depth of erosion varies significantly, reaching a maximum of a few hundred meters on October Revolution Island (Matukhin and Menner, 1999). The basal part of the Lochkovian deposits is usually represented by gravelly to pebbly conglomerate and coarse-grained sandstone, with the pebbles reworked from Silurian limestone and chert. The conglomerate and sandstone are overlain by alternating grayish argillite, marl and limestone of Early Lochkovian age. Upper Lochkovian strata comprise grayish sandstone and siltstone in the lower part of succession, and reddish argillite and siltstone with subordinate layers of dolomite and marl with celestine and barite concretions in the upper part. The Lochkovian age is substantiated by the 


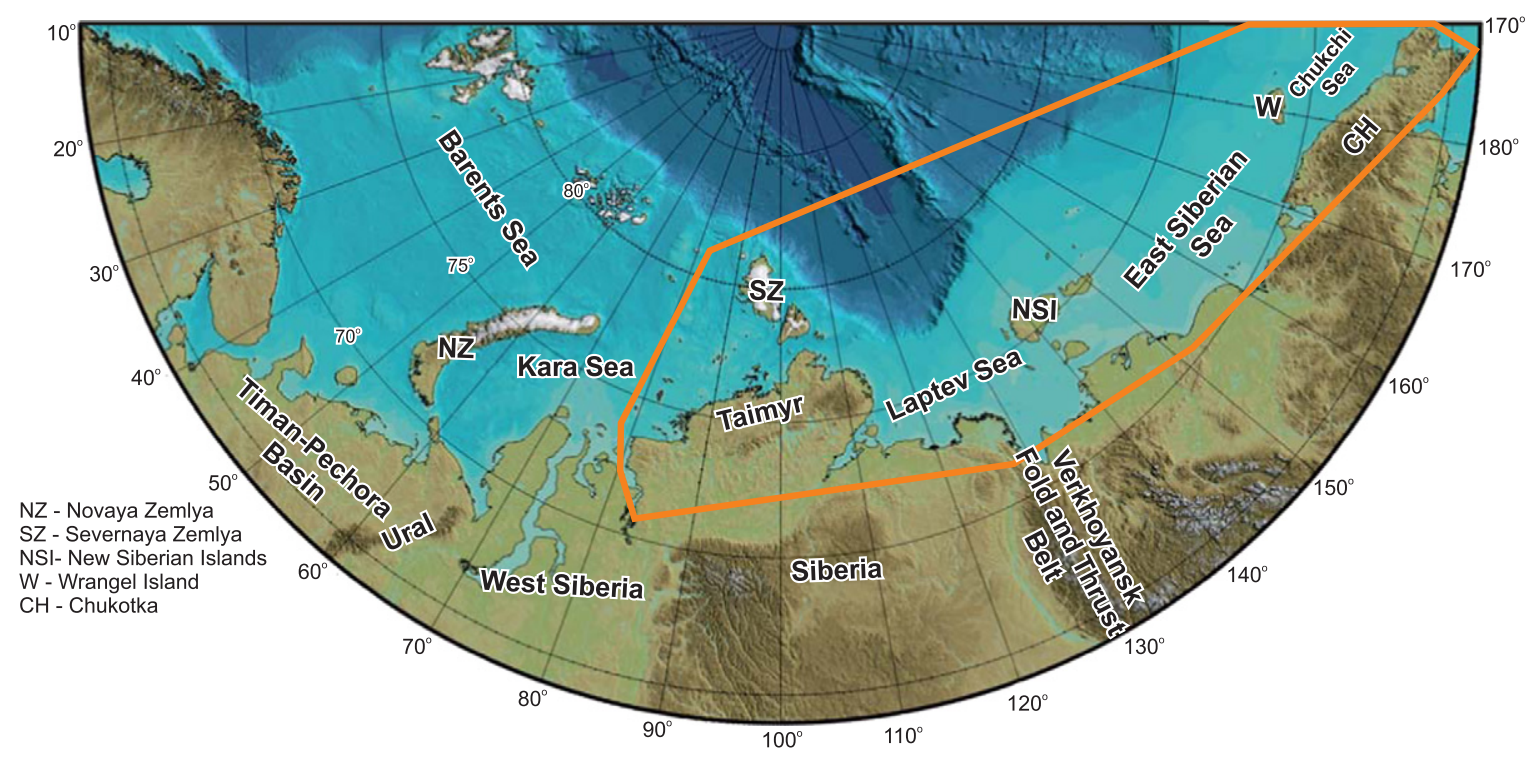

Fig. 1. Regional setting of the study area (orange outline shows the study area).

occurrence of ostracods and vertebrates throughout the succession (Matukhin and Menner, 1999). The thickness varies from 200 to $580 \mathrm{~m}$.

The 100-300 m thick Lower-Upper Pragian succession comprises varicolored sandstone, siltstone and argillite in the lower part, and grayish dolomitic marl with beds of dolomite and local gypsum layers in the upper part of the succession. The fossil assemblages mainly contain bivalves and vertebrates.

The uppermost Pragian-Lower Emsian strata are represented by a 80-300 m thick shallowing upward succession, comprising grayish bioclastic and stromatolitic limestone grading upwards to gypsum with subordinate marl layers (Menner et al., 1982). The limestone contains diverse marine fossils, including brachiopods, bivalves, ostracods, bryozoans, crinoids and corals.

The Upper Emsian strata on October Revolution Island comprise interbedded stromatolitic dolomite, marl, and bioclastic and stromatolitic limestone, with interbedded red sandstone and siltstone with ironstones at the top of succession. On Komsomolets Island, the Upper Emsian strata comprise alternating marl, stromatolitic limestone, bioclastic limestone and dolomite in the lower part of the succession, and argillite in the upper part. The Upper Emsian succession of Pioneer Island is represented by interbedded marl, micritic and bioclastic limestone. Ostracods and vertebrates have been recorded from October Revolution Island, while brachiopods and bivalves have been described from Pioneer Island (Matukhin and Menner, 1999). The thickness of Upper Emsian strata varies from 40 to $150 \mathrm{~m}$.

The Eifelian-Givetian succession of October Revolution Island comprises $340-400 \mathrm{~m}$ of alternating red sandstone, siltstone and clay. Locally, beds of dolomite, dolomitic marl and limestone have been described from the upper part of the succession. The coeval strata of Komsomolets Island are represented by $40-625 \mathrm{~m}$ of varicolored sandstone and siltstone. Red Eifelian-Givetian sandstone, siltstone and clay up to $100 \mathrm{~m}$ thick crop out on Pioneer Island.

Frasnian strata of October Revolution Island comprise alternating red sandstone, siltstone and argillite, with numerous vertebrates described from within the succession. Thin limestone beds with marine fossils occur in the upper part of the succession. The Frasnian deposits of Komsomolets Island are represented by intercalated reddish sandstone, siltstone and clay with rare vertebrates. Thin layers of limestone and marl occur in the upper part of the succession. The Frasnian strata of Pioneer Island comprise red sandstone, argillite and siltstone (Markovsky and Kulyasheva, 1993; Matukhin and Menner, 1999). The thickness of Frasnian sandstone reaches $1000 \mathrm{~m}$.
Lower Famennian deposits have only been described from the northern part of October Revolution Island and are represented by varicolored sandstone with lenses of conglomerates intercalated with siltstone and argillite (Khanin, 1982). The Devonian 220-260 m thick black argillite and siltstone, with rare layers of limestone and coalified plant detritus, mapped in the northern part of Bol'shevik Island, have been tentatively dated as Late Devonian-Early Carboniferous in age based on sparse palynological data, and overlie Cambrian deposits with a pronounced angular unconformity (Makariev, 2013; Markovsky et al., 1988).

1.1.1.2. Carboniferous-Permian. Carboniferous-Permian strata have been described from a few small exposures across the archipelago, but precise determination of their stratigraphic age is difficult and based on sparse palynological data (Dibner, 1982a,b; Makariev, 2013). In the western part of Bol'shevik Island, they are described as Lower Carboniferous based on spores and pollen (Dibner, 1982b).

Upper Carboniferous-Lower Permian deposits are exposed in the northeastern part of Bol'shevik Island, where they overlie Middle Cambrian folded strata with an angular unconformity. Plant spores and pollen indicate that the strata broadly span Late Carboniferous to Early Permian time (Dibner, 1982b; Gramberg and Ushakov, 2000; Makariev, 2013; Sobolev et al., 2013). The succession is mainly represented by an alternation of weakly cemented sandstone, siltstone and argillite, with lenses and layers of coal and coalified plant detritus with thickness up to $300 \mathrm{~m}$. Lenses and beds of quarzitic conglomerate occur throughout the succession (Ershova et al., 2015d).

Scattered exposures of Upper Carboniferous-Permian deposits up to $30 \mathrm{~m}$ thick have been described from October Revolution Island, where intercalated siltstone, sandstone and argillite with lenses and beds of conglomerate with coalified plant detritus commonly overlie Cambrian rocks with angular unconformity (Dibner, 1982a; Markovsky et al., 1984).

A thin succession of Guadalupian (?) deposits has been described from the western part of Komsomolets Island. This succession varies in thickness from 20 to $80 \mathrm{~m}$ and comprises intercalated sandstone and siltstone with subordinate beds of argillite and coal-bearing argillite lying with angular unconformity on Middle Devonian deposits (Markovsky and Kulyasheva, 1993) (Fig. 2).

\subsubsection{Paleogeography}

In general, sedimentary facies within the Devonian sedimentary basin of the Severnaya Zemlya Archipelago are indicative of a marine 

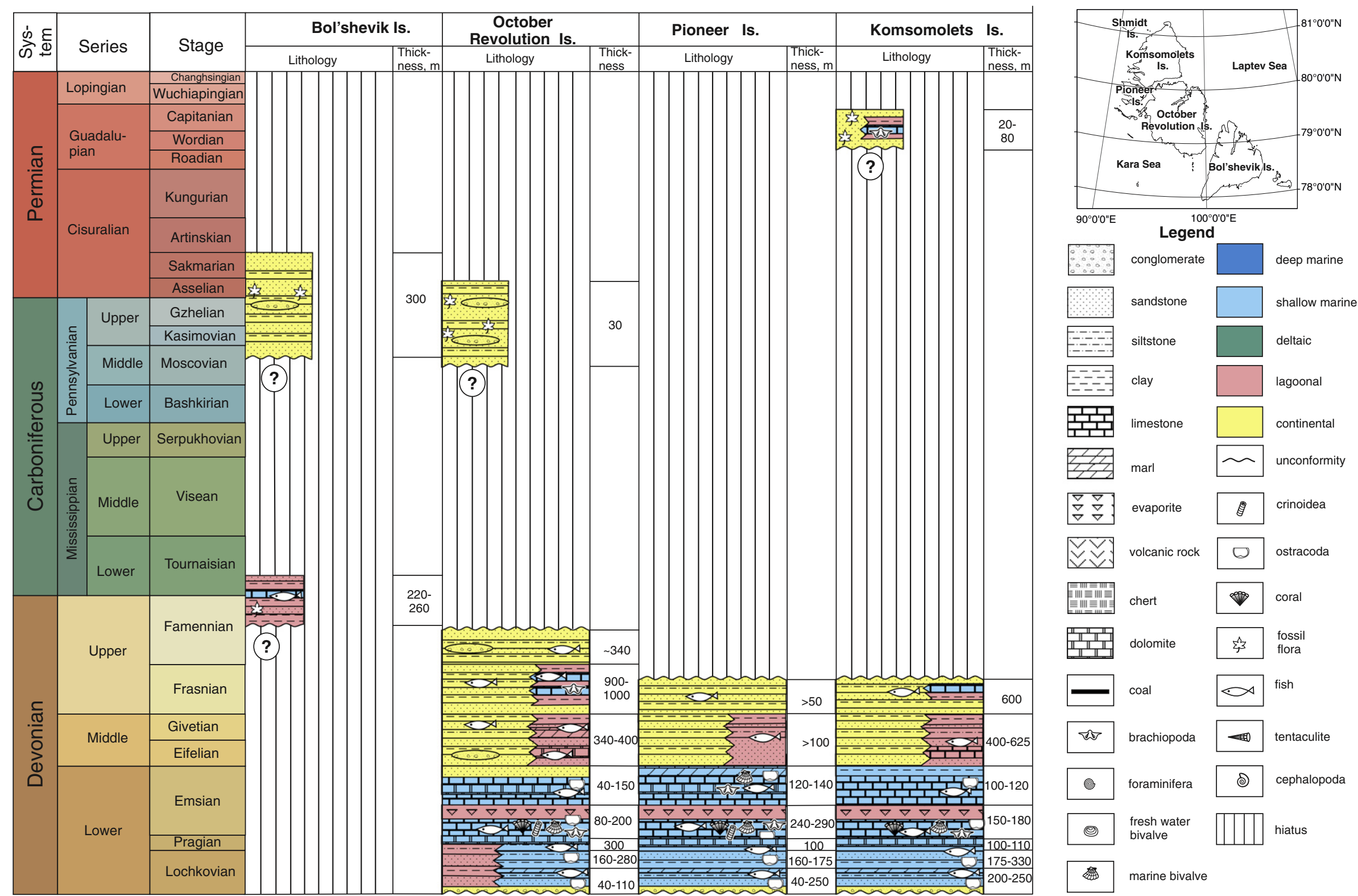

Fig. 2. Chronostratigraphic chart of Devonian-Permian deposits of Severnaya Zemlya Archipelago

Data sources: Dibner, 1982a,b; Ershova et al., 2015d; Gramberg and Ushakov, 2000; Makariev, 2013; Matukhin and Menner, 1999; Menner et al., 1982; Markovsky et al., 1984, 1988; Markovsky and Kulyasheva, 1993; Khanin, 1982; Sobolev et al., 2013). 
transgression in the Early Devonian, followed by a major regression in the Late Devonian. Early Devonian transgression led to the deposition of predominantly marine clastic rocks within the basin, become increasingly open-marine towards the northwest (in present-day coordinates) (Fig. 3). The initial marine transgression took place during the Early Lochkovian, with sedimentary facies across the Severnaya Zemlya Archipelago illustrating a transition from continental to lagoonal to shallow marine depositional environments upwards through the succession. By the Late Lochkovian to Early Pragian, clastic sediments accumulated within a shallow epicontinental sea (in the northwest) and in brackish water lagoons and continental fluvial-lacustrine environments (towards the southeast) (Fig. 3).

Maximum transgression occurred at the end of the Pragian and Early Emsian, when shallow marine carbonates were deposited across much of the archipelago. The presence of a diverse suite of brachiopods, bivalves, stromatoporoids, tabulate corals and crinoids indicates that normal marine salinities covered much of the archipelago during this time. The salinity of these waters significantly increased by the middle of the Emsian, leading to deposition of a correlatable gypsum unit across the archipelago. The Late Emsian is characterized by a second marine transgression, manifested in the geological record by deposition of shallowmarine and lagoonal carbonates and argillite. Marine regression resulted in deposition of a continental red sandstone unit across October Revolution Island at the end of the Emsian, while shallow marine carbonates and argillite continued to accumulate across Pioneer and Komsomolets islands. The Late Emsian fossil assemblages are suggestive of a transition from brackish environments in the southeast to normal marine environments in the northwest, as typical marine invertebrates are present within the uppermost Emsian strata on Komsomolets Island.

The Middle-Upper Devonian sedimentary succession is much thicker than the Lower Devonian and reaches up to $1.5 \mathrm{~km}$ thick. Middle Devonian strata are characterized by varicolored clastic rocks, with rare fossils mainly represented by a variety of vertebrates and ostracods. Upper Devonian sediments mainly consist of red clastic rocks, including sandstone, siltstone and mudstones with local interbeds of limestone. Fossil assemblages and sedimentary facies indicate the development of alluvial to lagoonal environments in the Middle-Late Devonian across the Severnaya Zemlya Archipelago (Fig. 3).

Throughout the archipelago, Carboniferous-Permian deposits are distributed locally and represented mainly by clastic continental deposits. At this time, most of the archipelago represented a subaerial landmass, with deposition of relatively thin continental deposits within local depressions (Fig. 3).

\subsection{South-Central Taimyr and northern Siberia (Lena-Anabar Depression and Lower Lena areas)}

\subsubsection{Stratigraphy}

1.2.1.1. South-Central Taimyr. Devonian-Permian deposits crop out in the southern and central part, but there are no middle-upper Paleozoic strata in the northernmost part of the Taimyr Peninsula (Pogrebitskiy and Lopatin, 1999a,b; Pogrebitskiy and Shanurenko, 1998a,b). The northernmost Taimyr together with Severnaya Zemlya Archipelago compose an exotic block called the Kara Terrane (Lorenz et al., 2008b; Parfenov et al., 2003; Zonenshain et al., 1990) which accreted to Siberia during the Carboniferous.

1.2.1.1.1. Devonian. The Devonian is represented by two different successions with significant facies changes from the south to the north (Pogrebitskiy and Lopatin, 1999a,b; Sobolev, 1997). In the south, the Lower Lochkovian deposits are represented by intercalated gypsum, dolomite and dolomitic argillite at the base, grading upwards to dolomite, limestone and argillite. The fossil record here contains euryhaline species of lingulid brachiopods, ostracods, and locally, bivalves and gastropods. The Upper Lochkhovian-Lower Emsian succession is represented by very fossil-rich bioclastic limestone with interbedded argillite and dolomite. To the north, the succession changes to intercalated dolomite and limestone. The abundant marine fossils include bryozoans, crinoids, brachiopods, ostracods and corals. The interbedded argillite becomes less important towards the east, where mainly carbonates were deposited. The thickness of Lochkovian-Lower Emsian deposits reaches up to 1200 m (Sobolev, 1997). Northward, the Lochkovian-Emsian carbonates are substituted by alternating black argillite, siliceous argillite, chert and limestone (Sobolev, 1997 and references therein). The 2601300 m thick Upper Emsian-Middle Devonian deposits of South and Central Taimyr are represented by dolomite with beds of algal limestone and marl, with rare brachiopods, corals and ostracods found within the limestone. A monotonous coeval succession of argillite and chert, which is reportedly barren of fossils, was deposited across the Central Taimyr (up to $240 \mathrm{~m}$ ). The Frasnian-Famennian deposits comprise a 170$740 \mathrm{~m}$ thick succession of limestone and dolomitized limestone across South Taimyr, with rare brachiopods and gastropods and some beds of carbonate conglomerate found in the middle part of the succession. To the north, coeval strata are represented by interbedded micritic limestone, black argillite and siliceous argillite. The total thickness of Devonian deposits in reaches up to $2100 \mathrm{~m}$, but thins to $700 \mathrm{~m}$ or less to the north (Fig. 4).

1.2.1.1.2. Carboniferous. The Lower Carboniferous succession of Taimyr displays a similar facies zonation as in the Devonian basin. In the northern facies zone, Lower Carboniferous strata comprise a 400$560 \mathrm{~m}$ thick succession of black argillite with subordinate beds of limestone with rare foraminifers (Pogrebitskiy and Shanurenko, 1998a,b; Sobolev, 1999). Meanwhile, a shallower marine succession of up to $1400 \mathrm{~m}$ of interbedded bioclastic and micritic limestone with subordinate beds of argillite and chert have been described from South Taimyr, with bioclastic and sandy limestone becoming more abundant in the upper part of the succession. The diverse marine fossil assemblages have resulted in the identification of each stage of the Lower Carboniferous within these deposits (Pogrebitskiy and Shanurenko, 1998a,b; Pogrebitskiy and Lopatin, 1999a,b; Sobolev, 1999). The Bashkirian deposits across Taimyr mark the transition from carbonate to clastic sedimentation. A basal 60 m-thick carbonate breccia of Early Bashkirian age has been reported from Central Taimyr (Pogrebitskiy and Shanurenko, 1998a,b). The Bashkirian-Sakmarian strata are represented mainly by alternating siltstone and argillite with subordinate beds of sandstone, with thickness of the succession increasing from $300 \mathrm{~m}$ in the west to $1100 \mathrm{~m}$ in the east. Their age has been substantiated by rare occurrences of foraminifers, brachiopods and fossil plants (Pogrebitskiy and Shanurenko, 1998a,b; Pogrebitskiy and Lopatin, 1999a,b; Shishlov et al., 1997).

1.2.1.1.3. Permian. The Artinskian deposits conformably overlie the Upper Carboniferous-Sakmarian succession, and are represented by $300-800 \mathrm{~m}$ of interbedded sandstone, siltstone and argillite across Taimyr, with rare beds of clayey limestone and coal in the west. The 200-600 m thick Kungurian deposits of northwestern Taimyr comprise interbedded sandstone, siltstone and conglomerate with thick coal beds. So far, no marine fossils have been reported from the unit; therefore the age of the deposits has been established based on the terrestrial floral assemblage. In the east of Taimyr, the Kungurian strata comprise up to $500 \mathrm{~m}$ of interbedded siltstone and sandstone, with subordinate thin beds of coal and rare findings of euryhaline bivalves. The MiddleUpper Permian strata of South Taimyr consist of alternating sandstone and siltstone with beds of coal and abundant coalified plant detritus, with estimated thickness ranging from $700 \mathrm{~m}$ in the west to $2000 \mathrm{~m}$ in the east of Taimyr. The proportion of fine-grained deposits increases, while the number and thickness of coal beds decreases, in a west to east transect across Taimyr (Pogrebitskiy and Shanurenko, 1998a,b; Proskurnin et al., 2013), with marine fossils only found across eastern Taimyr (Fig. 4). The uppermost Permian succession comprises alternating tuff, tuffaceous sandstone and basalt flows up to $350 \mathrm{~m}$ thick (Pogrebitskiy and Lopatin, 1999a,b). 


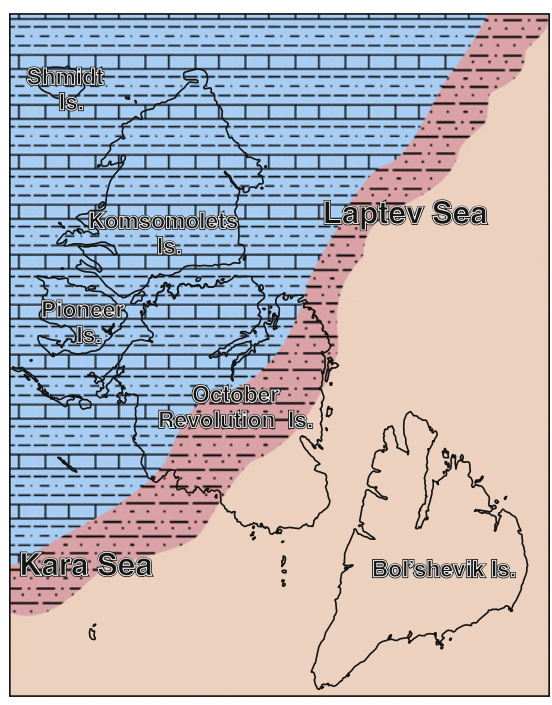

Early Lockhovian

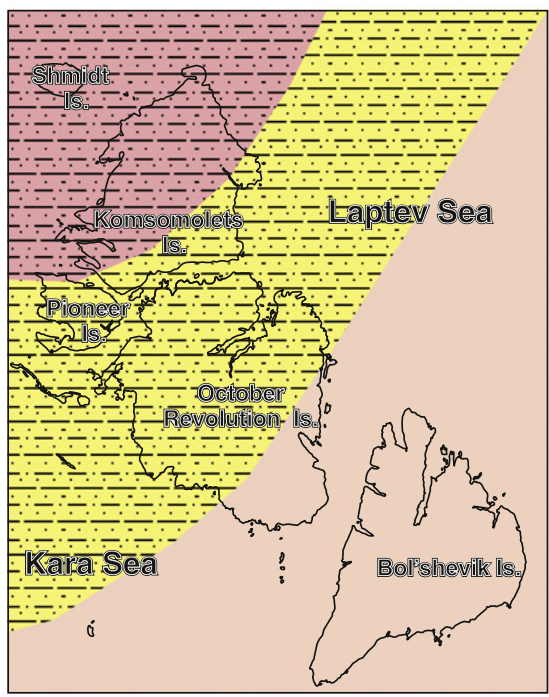

Early Eifelian

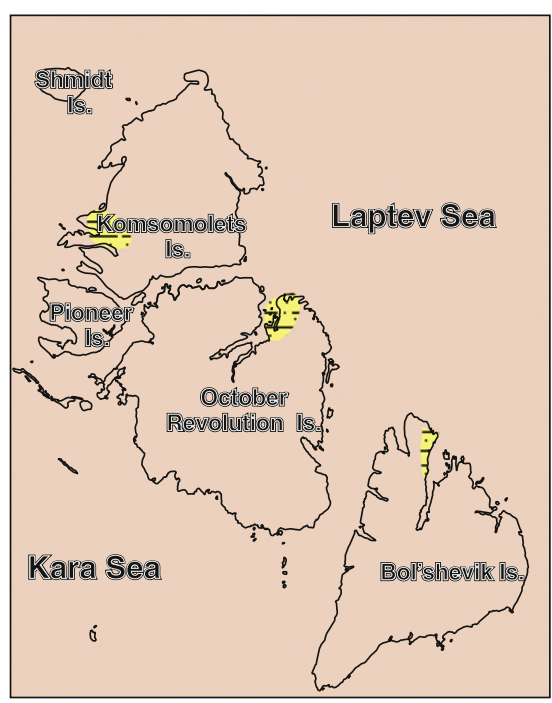

Late Carboniferous- Earliest Permian

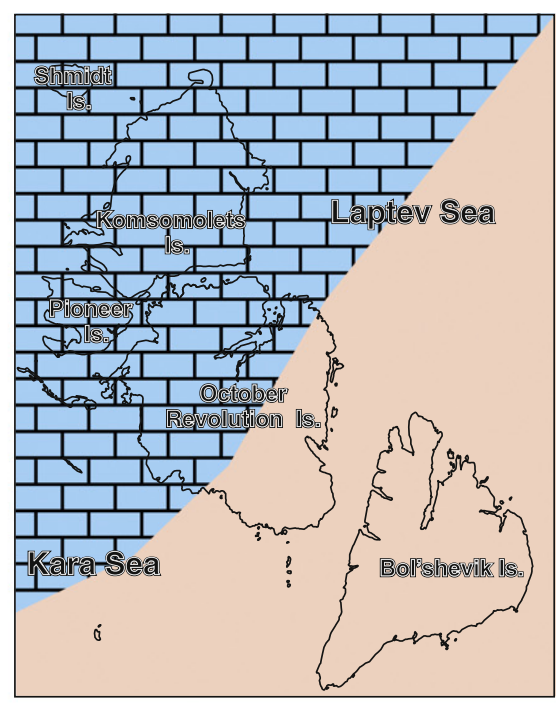

Early Emsian

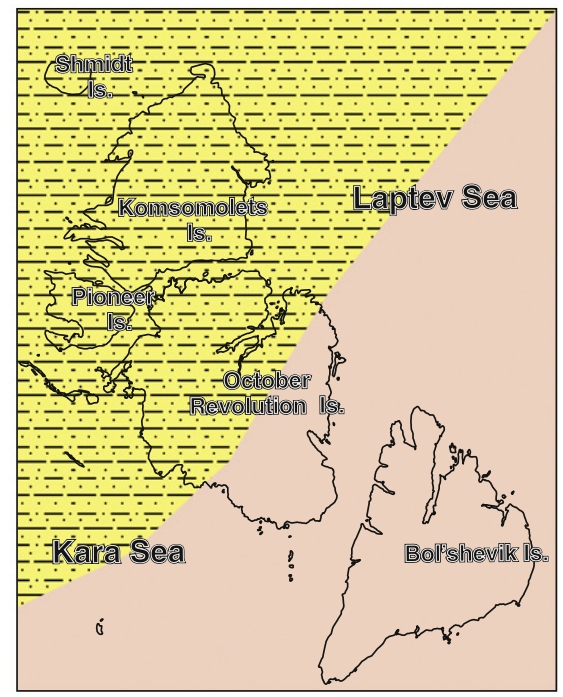

Early Frasnian

Legend

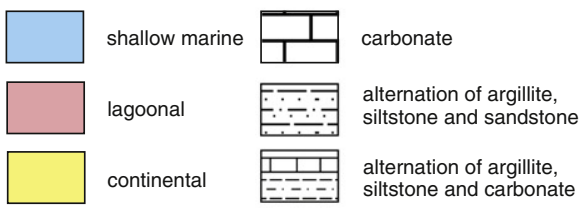

lowland

Fig. 3. Paleogeographic maps for Devonian-Permian of Severnaya Zemlya Archipelago (data sources, as for Fig. 2). 

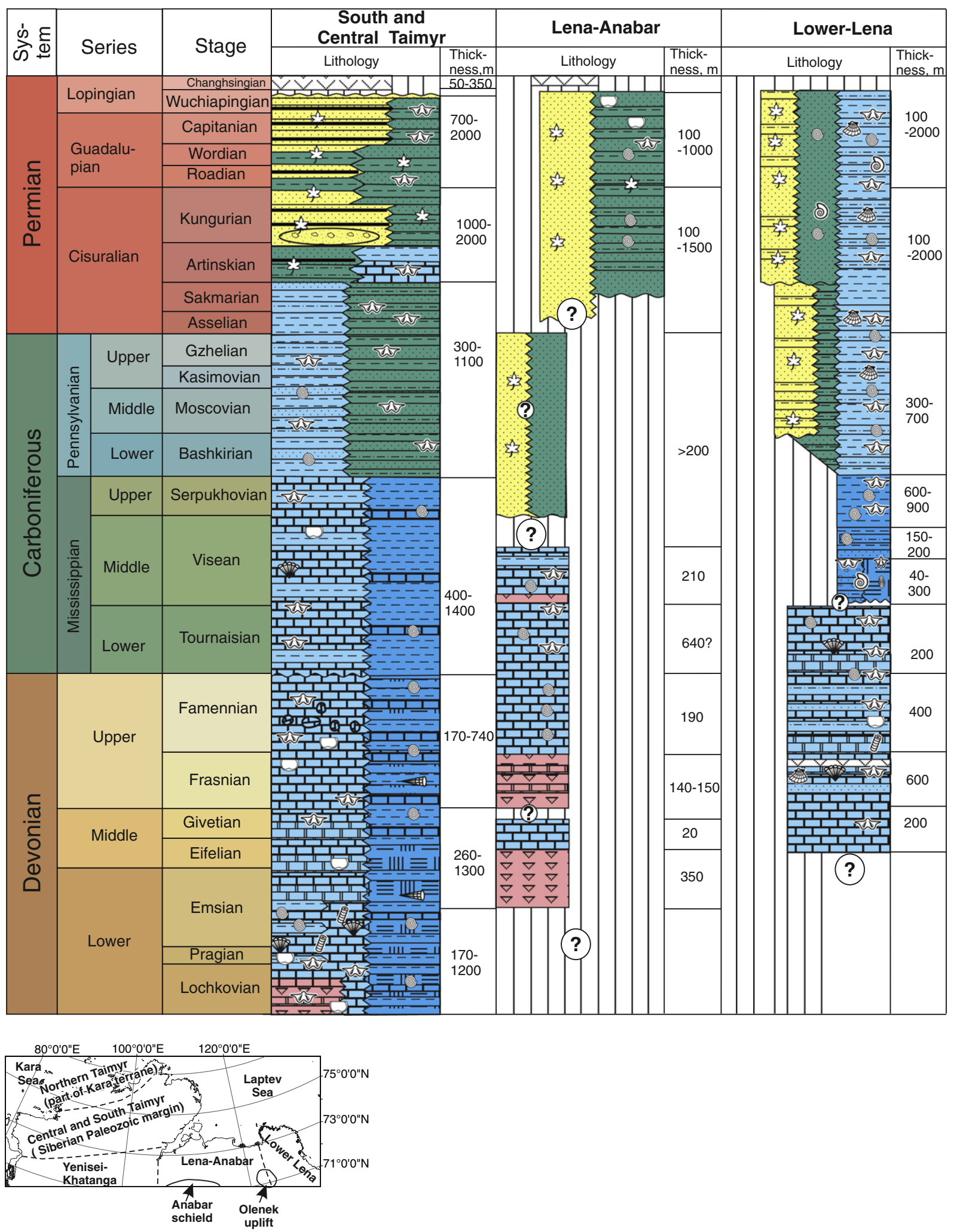

Fig. 4. Chronostratigraphic chart of Devonian-Permian deposits of South-Central Taimyr and northern Siberia (see legend on Fig. 2).

(Data sources: Abramov and Grigorieva, 1983, 1986; Budnikova et al., 1991; Bulgakova, 1967; Egorov, 1993; Egorov and Andreev, 1981; Ershova et al., 2012, 2014; Gogina, 1979; Kalinko, 1953; Kontorovich et al., 2013; Matukhin, 1991; Matukhin et al., 1995; Menner and Sidyachenko, 1975; Mezhvilk and Markov, 1983; Pogrebitskiy and Lopatin, 1999a,b; Pogrebitskiy and Shanurenko, 1998a,b; Prokopiev et al., 2001; Proskurnin et al., 2013; Shishlov et al., 1997; Sobolev, 1997, 1999; Solomina, 1997; Vanin et al., 2001; Yazikov et al., 2013). 
1.2.1.2. Lena-Anabar Depression. The Devonian-Permian sedimentary succession of the Lena-Anabar Depression can only be constructed based on a few deep wells drilled in the 1950s-1980s. The oldest rocks exposed at the surface along the southern basin margin and in the Olenek Fold Belt are of Permian age, except for local exposures of buoyant Devonian salt diapirs which have pierced to the surface.

1.2.1.2.1. Devonian. The Devonian strata have been found only in the northwest of the Lena-Anabar Depression (Nordvik Peninsula), where they have been penetrated by a few wells, crop out in a salt dome, and have been traced on seismic lines (Kalinko, 1953; Matukhin, 1991; Matukhin et al., 1995). The lowest known part of the Devonian section comprises more than $250 \mathrm{~m}$ of halite, including a 5-6 m thick layer of mirabilite, overlain by $60 \mathrm{~m}$ of interbedded gypsum and anhydrite. The formation has been tentatively dated as Late Emsian-Eifelian, based on a stratigraphic position directly below deposits containing Eifelian fossils and correlation with neighboring regions (Fig. 4).

The overlying 20 m-thick unit of limestone contains Late Eifelian conodonts in the lower part and Givetian brachiopods in the upper. The Upper Devonian unit lies on the erosional surface of an EifelianGivetian limestone, comprising $10 \mathrm{~m}$ of gypsum at the base, followed upward by $40 \mathrm{~m}$ of dolomite with beds of gypsum, and then a $20 \mathrm{~m}$ thick gypsum bed overlain by $20 \mathrm{~m}$ of dolomitic limestone. These Upper Devonian deposits are capped by a 50-60 m thick gypsum bed. The age of this unit, based on its stratigraphic position within the Devonian succession, is assumed to be Frasnian (Matukhin, 1991). The uppermost Devonian deposits have been penetrated by a single well and are represented by more than $170 \mathrm{~m}$ of limestone of Famennian age based on foraminifers (Matukhin et al., 1995).

1.2.1.2.2. Carboniferous. Carboniferous deposits have been penetrated in the Nordvik area of the north-western Lena-Anabar Depression, where they comprise $640 \mathrm{~m}$ of Tournaisian micritic limestone and $210 \mathrm{~m}$ of Visean bioclastic limestone with beds of anhydrite (Pogrebitskiy and Shanurenko, 1998a,b). The Lower Carboniferous carbonates in the northwest of the Lena-Anabar Depression are overlain by a relatively thick succession of alternating sandstone, siltstone and argillite. Early Permian spores, pollen and foraminifers have been found only in the upper part of the overlying clastic succession, therefore the lower part of this overlying succession has been assumed to be Late Carboniferous in age (Proskurnin et al., 2013). Upper Carboniferous clastics also were described from the Ust'-Olenek Well in the northeast of the LenaAnabar Depression (Budnikova et al., 1991; Prokopiev et al., 2001), however more recently Kontorovich et al., 2013 dated these clastics as Early Permian in age (Fig. 4).

1.2.1.2.3. Permian. Permian deposits of the Lena-Anabar Depression are mostly covered by a thick Mesozoic succession. They are exposed along the northern margins of the Anabar Shield and Olenek Uplift, as well as within the Olenek Fold Belt, while in the basin interior they are penetrated by deep wells. The whole Permian succession comprises interbedded sandstone, siltstone and clay. Permian strata in this area display a facies zonation from entirely continental deposits only a few tens of meters thick in the south, along the northern margins of the Anabar shield and Olenek Uplift, to brackish and marine clastics up to $2400 \mathrm{~m}$ thick in the north (Pogrebitskiy and Shanurenko, 1998a,b).

In the northwest of the Lena-Anabar Depression, the Lower Permian deposits comprise $900-1200 \mathrm{~m}$ of alternating sandstone, siltstone and argillite, while Middle-Upper Permian deposits are 600-800 m thick. The ages have been determined based on foraminifers and floral assemblages (Proskurnin et al., 2013). In the eastern part of the Lena-Anabar Depression, Lower Permian deposits unconformably overlie Precambrian-lower Paleozoic rocks and comprise a succession of intercalated siltstone, sandstone and argillite with coal beds. Thickness of the Lower Permian succession varies from a few hundred meters in the south to up to $1500 \mathrm{~m}$ in the north, with a decrease in abundance of sandstone and increase in proportion of siltstone and argillite in the same direction. The stratigraphic age is based on spores, pollen and foraminifers (Vanin et al., 2001). The Middle-Upper Permian succession is similar in composition to the Lower Permian, with thickness varying from a few hundred to $1000 \mathrm{~m}$ (Fig. 4). Scattered beds of pebbly to gravelly conglomerate have been described from the easternmost outcrops. The fossils reported here include foraminifers, rare brachiopods and ostracods (Vanin et al., 2001).

1.2.1.3. Lower Lena area. The Lower Lena area represents the northeastern margin of the Siberian Platform and northern part of the Verkhoyansk Fold and Thrust Belt (FTB). It formed as a result of late Mesozoic collision of the Kolyma-Omolon Superterrane with Siberian paleocontinent following closure of the Oimyakon Ocean, and comprises a thick deformed marine sedimentary wedge of the eastern passive margin of Siberia (Khudoley and Prokopiev, 2007; Parfenov, 1991).

1.2.1.3.1. Devonian. Lower Devonian strata are missing from northeastern Siberia due to either subsequent erosion or non-deposition, but Middle to Upper Devonian rocks are exposed at several locations in the northern part of the Verkhoyansk FTB and in the Lena River Delta area (Menner and Sidyachenko, 1975; Prokopiev et al., 2001). Middle Devonian rocks have been found within a single tectonic block in the northern part of Verkhoyansk FTB (Kharaulakh Anticlinorium), where they are represented by $200 \mathrm{~m}$ of limestone and dolomitized limestone. The Middle Devonian age of these strata is based on the occurrence of corals and brachiopods (Gogina, 1979). Frasnian deposits mainly comprise limestone and dolomitized limestone, with a 300 m-thick unit of basalt flows within the middle part of the succession, related to rifting along the eastern margin of Siberia (Gogina, 1979). The limestone contains a diverse assemblage of brachiopods, corals, bivalves and pteropods. The Famennian deposits are up to $400 \mathrm{~m}$ thick and comprise alternating calcareous sandstone and siltstone with subordinate marl and limestone (Gogina, 1979; Menner and Sidyachenko, 1975; Yazikov et al., 2013) (Fig. 4).

1.2.1.3.2. Carboniferous. Carboniferous outcrops, as with the Devonian, occur within uplifted thrust sheets in the front of Verkhoyansk FTB, but are buried beneath a thick succession of younger deposits in the adjacent part of the Siberian Platform. Further to the south, they have been eroded. Tournaisian strata conformably overlie Famennian deposits and comprise a succession of bioclastic limestone with chert nodules, up to $200 \mathrm{~m}$ in thickness (Abramov and Grigorieva, 1986). The Lower Visean sedimentary succession comprises two lithologically contrasting units: coarse-grained turbidites ( $300 \mathrm{~m}$ thick) in the northern part of the area, and hemipelagic cherts (around $50 \mathrm{~m}$ thick) in the south (Bulgakova, 1967; Ershova et al., 2013, 2014; Prokopiev et al., 2013). The Upper Visean succession is represented by coarse- to mediumgrained sandstone at its base, fining upwards to siltstone and argillite at the top of the succession (150-200 m thick). The uppermost Visean-Serpukhovian deposits comprise a succession of argillite with local thin sandstone and siltstone beds, ranging in thickness from 600 to $900 \mathrm{~m}$ (Abramov and Grigorieva, 1986). The Upper Carboniferous strata are represented by a succession of marine argillite, siltstone and sandstone, with a total thickness of up to $700 \mathrm{~m}$ in the east (Fig. 4), while in the west up to $115 \mathrm{~m}$ of coeval continental clastics are found (Smetannikova et al., 2013). The age of the marine Carboniferous deposits is substantiated by a diverse assemblage of brachiopods (Abramov and Grigorieva, 1983), and the continental deposits by floral assemblages (Smetannikova et al., 2013).

1.2.1.3.3. Permian. Permian strata across much of the Lower Lena area also are covered by a thick Mesozoic succession. They lie conformably on the Upper Carboniferous rocks in much of the northern part of Verkhoyansk FTB (Kharaulakh Anticlinorium) while in the adjacent part of Siberian Platform Permian strata lie directly on Cambrian carbonates with all other Paleozoic units missing (Ershova et al., 2012; Prokopiev et al., 2001). The Permian deposits crop out along the eastern margin of the Olenek Uplift and in the northern part of the front of Verkhoyansk FTB (Kharaulakh Anticlinorium), and have been penetrated by a few wells elsewhere. The Permian sediments in the west are represented by a few hundred meters of mainly continental sandy deposits with layers of conglomerate, fining eastward to interbedded siltstone, clay and 
sandstone (Mezhvilk and Markov, 1983). Permian strata display a facies transition from entirely continental deposits in the west to marine in the east. Continental sedimentation did not commence in the western part of the area until the Artinskian, while a stratigraphically complete Permian marine succession has been described from the east (Egorov, 1993; Egorov and Andreev, 1981; Solomina, 1997), with an increasing thickness from a few hundred meters to a few kilometers in an eastward direction. In the easternmost outcrop within the front of northern part of the Verkhoyansk FTB (Kharaulakh Anticlinorium), thick olistostrome units have been found (Egorov and Andreev, 1981).

\subsubsection{Paleogeography}

Early Devonian marine sedimentation was widespread across the northwest of the study area in South and Central Taimyr, where limestone and dolomite with beds of evaporites in the south grade northward into black argillite and chert. This facies distribution marks the transition from shallow to deep-marine environments in a northward direction across Taimyr (present-day coordinates). The presence of evaporites in the Lower Devonian succession marks the existence of Early Devonian hypersaline lagoons along the coastal and marginal parts of the basin to the south. This Early Devonian coastal zone can be traced eastward into the western part of the Lena-Anabar Depression, based on the occurrence of upper Lower Devonian evaporites there as well (Fig. 5).

The Middle Devonian sedimentary succession inherited the distribution of facies from the Early Devonian basin, illustrating a similar deepening of the marine environment northward across Taimyr, while shallow water carbonates accumulated in the south. Evaporite deposition continued in coastal to lagoonal environments across the western part of Lena-Anabar Depression, while the shallow marine carbonate sedimentation can be traced eastward to outcrops in the northern part of the Verkhoyansk FTB.

The Late Devonian basin across Taimyr continued to deepen from the south to the north. The presence of marine limestone and calcareous sandstone in the western part of Lena-Anabar Depression provide evidence for expansion of the shallow marine basin during the Late Devonian, while the occurrence of interbedded dolomite suggest periods of elevated salinity within a partially restricted basin.

No Devonian deposits have been reported to date in a zone between the western part of the study area (Taimyr and westernmost part of the Lena-Anabar Depression) and the eastern part (Verkhoyansk FTB), possibly due to the presence of an area of lowland with limited denudation here, or subsequent erosion of the Devonian deposits. Therefore, there is no direct evidence of a connection between the Middle-Late Devonian basins of the eastern and western parts of northern Siberia.

The main Late Devonian tectonic event manifested across northeastern Siberia is the accumulation of Frasnian basalts related to Late Devonian-Early Carboniferous rifting, expressed along the entire eastern margin of Siberia (Gaiduk, 1988; Khudoley and Guriev, 2003; Parfenov, 1984, 1991; Prokopiev et al., 2001). This rifting resulted in the formation of a number of discrete horsts and grabens across eastern Siberia, however these are mainly described from southeastern Siberia and so far, no evidence for these grabens has been found across northeastern Siberia.

The Early Carboniferous basin displays the same transition from shallow marine carbonates to relatively deep water argillite from south to north across Taimyr. The shallow water bioclastic carbonates with rare beds of anhydrite in the western Lena-Anabar Depression represent the marginal deposits of the marine basin located to the north across Taimyr. The earliest Carboniferous bioclastic carbonates across the eastern margin of Siberia (Verkhoyansk FTB) were deposited in a shallow epeiric sea. An abrupt shift in depositional environment occurred here during the Visean, when shallow water carbonate sedimentation was terminated and replaced by deep marine coarse-grained turbidites and cherts deposited in hemipelagic environments (Ershova et al., 2013, 2014; Prokopiev et al., 2013). Chert deposition across the northeastern margin of Siberia was temporarily interrupted by the pulsed input of coarse clastic turbidites as small sandy submarine fans during this time. The Visean strata have been interpreted as the oldest post-rift strata along the eastern passive margin of Siberia (Ershova et al., 2013, 2014; Prokopiev et al., 2013), with the remainder of the Lower Carboniferous (Upper Visean-Serpukhovian) post-rift succession represented by mainly fine-grained turbidites.

The Upper Carboniferous succession of Taimyr is characterized by a marked shift from siliceous-carbonate sedimentation during the earliest Late Carboniferous to clastic deposition. A relatively thick succession of shallow-marine to deltaic clastics accumulated across this area throughout the Late Carboniferous, while submarine fan turbidites were deposited along the passive eastern margin of Siberia (Fig. 5).

Lower Carboniferous strata have not been discovered in the central and eastern part of the Lena-Anabar Depression and there are controversial opinions regarding the distribution of Upper Carboniferous strata there (Budnikova et al., 1991; Kontorovich et al., 2013), therefore the existence of a connection between Carboniferous basins of the western and eastern parts of the northern margin of Siberia is still debatable, as with the Devonian.

The Permian strata of Taimyr are characterized by mainly shallowmarine to deltaic deposits. The Lower Permian sedimentary facies of western Taimyr are characteristic of the infilling of a sedimentary basin, with an upward transition from marine-lagoonal to mainly fluvial-lacustrine deposits, while mainly marine clastics were deposited across eastern Taimyr throughout this time (Shishlov et al., 1997). The Upper Permian succession of Taimyr is represented mainly by continental deposits with thick coal beds deposited in fluvial-lacustrine depositional environments, grading into deltaic-shallow marine deposits towards the east (Shishlov et al., 1997). The Early Permian in the Lena-Anabar and Lower Lena areas is characterized by a significant marine transgression resulting in widespread deposition of Lower Permian deposits across these regions, where they unconformably overlie Proterozoic and Paleozoic strata. Permian deposits conformably overlie Upper Carboniferous rocks only in the easternmost part of the Lower Lena area (Mezhvilk and Markov, 1983). The Permian succession displays a gradational transition from continental to deltaic-shallow marine environments in a northward direction across the Lena-Anabar Depression. The Permian deposits across the Lower Lena area display a transition from continental to shallow marine-deltaic to more deep marine successions in an eastward direction, forming a classic sedimentary succession developed along a mature passive margin (Fig. 5).

\subsection{New Siberian Islands}

The New Siberian Islands represent an exposed Paleozoic-Mesozoic crustal fragment located in the eastern part of the Russian Arctic, between the Laptev and East Siberian Seas. The archipelago consists of three island groups: the Anzhu Islands (Kotel'ny, Bel'kovsky and Novaya Sibir islands), the Lyakhovsky Islands (Stolbovoy, Malyi Lyakhovsky and Bol'shoy Lyakhovsky islands) (Fig. 6), and the De Long Islands in the north (Jeannette, Henrietta, Bennett, Zhokhov and Vil'kitskiy islands). Devonian-Permian deposits have been described from Kotel'ny, Bel'kovsky and Bol'shoy Lyakhovsky islands. The most complete Paleozoic sections have been described from Kotel'ny Island, while a less complete section is exposed on Bel'kovsky and Bol'shoy Lyakhovsky islands (Kos'ko et al., 2013).

\subsubsection{Stratigraphy}

1.3.1.1. Kotel'ny Island. The most complete Devonian-Permian sections are located along the west coast of the island, with only scattered exposures in deeply cut riverbeds across the central part of the island. The patchy distribution of outcrops therefore resulted in some difficulties in correlating stratigraphy across the island.

1.3.1.1.1. Devonian. The Lochkovian deposits lie conformably on Silurian carbonates and are represented by alternating micritic, bioclastic 

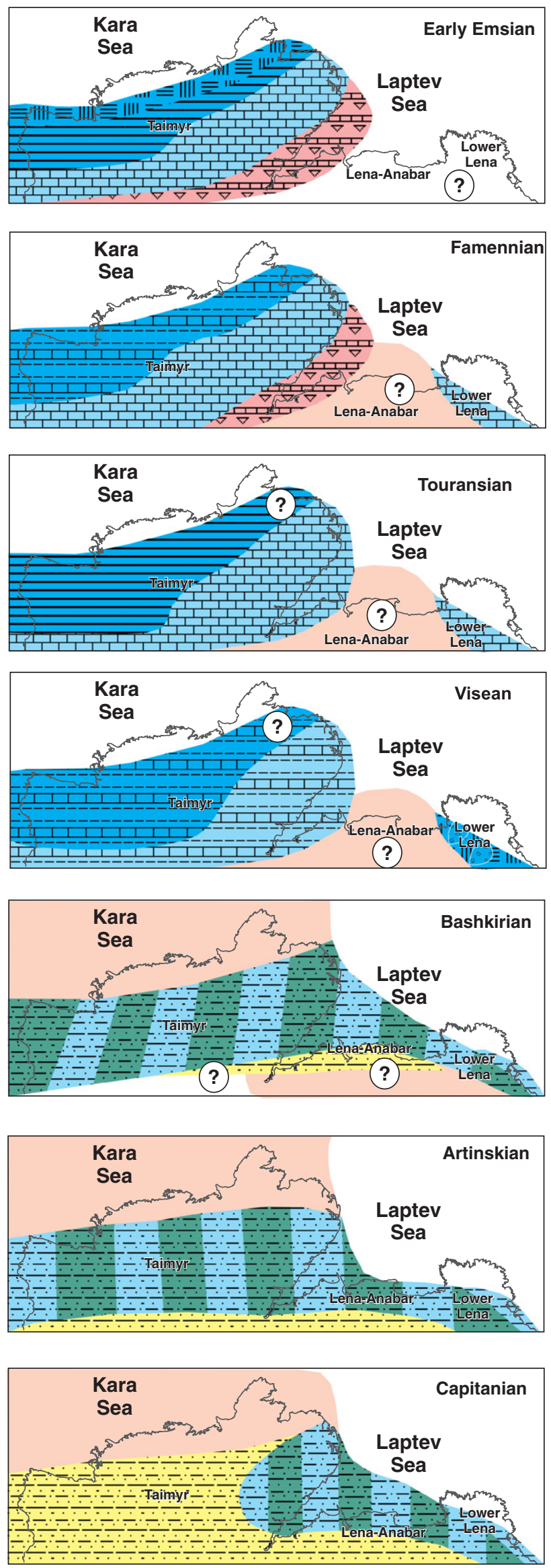

Fig. 5. Paleogeographic maps for Devonian-Permian of South-Central Taimyr and northern Siberia (data sources as for Fig. 4)

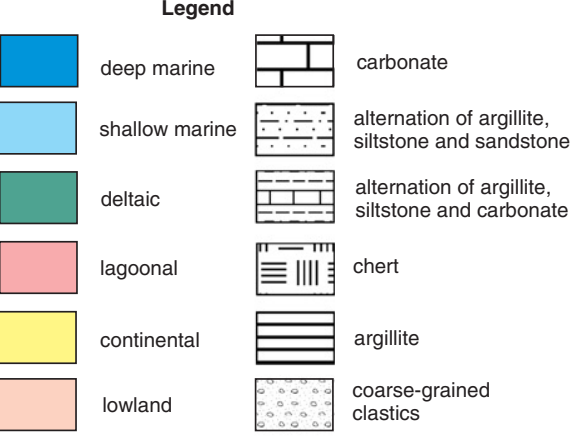


and clayey limestone, marl and dolomite, with subordinate beds of clay. Dolomite beds have not been described from the south of the island. The thickness of the Lochkovian succession varies from 200 to $400 \mathrm{~m}$. The strata are characterized by fossiliferous limestone, yielding a diverse array of marine fossils including brachiopods, corals, ostracods, tentaculites, gastropods and bivalves, and poorly fossiliferous dolomitic units with depleted faunal assemblages (Fig. 6) (Kos'ko et al., 1972; Cherkesova, 1972).

Pragian-Lower Emsian deposits (165-300 m thick) comprise micritic and bioclastic limestone with subordinate beds of clayey limestone in the northwestern part of the island, while in the southeastern part micritic thinly bedded limestone and black argillite were deposited. The characteristic feature of these deposits in the northwestern part of Kotel'ny Island is the abundant fragments of colonial corals throughout succession. The Pragian succession contains a diverse array of marine fossils including brachiopods, corals, tentaculites, ostracods and trilobites (Cherkesova, 1972).

The uppermost Lower Emsian-Upper Emsian strata are represented by bioclastic highly bituminous limestone with subordinate beds of black marl in the northwestern part of the island, while in the southwestern part the strata consist of micritic limestone with beds of argillite, reaching an estimated thickness of about $300 \mathrm{~m}$. These strata are characterized by a diverse array of marine fossils including bryozoans, tentaculites, brachiopods, corals and crinoids.

The Middle Devonian (Eifelian-Givetian) strata lie unconformably on Lower Devonian and Silurian deposits in the northern part of the island, and conformably in the south (Kos'ko et al., 1985). The strata are up to $600 \mathrm{~m}$ thick and are represented by alternating bioclastic and micritic limestone, with thick beds of carbonate breccia comprising angular clasts of pebble and boulder size (up to $5 \mathrm{~m}$ in diameter). Thick breccia beds have been reported from both the northern and southern parts of the island, however only bioclastic, micritic, coralline and clayey limestone have been described from the sparse outcrops in the central part of the island. The Middle Devonian succession contains diverse marine benthic fossil assemblages (Kos'ko et al., 1972; Cherkesova, 1972).

The Frasnian deposits lie unconformably on Middle Devonian carbonates (Prokopiev et al., 2015) and comprise $50 \mathrm{~m}$ of alternating varicolored green and red clay and siltstone with subordinate beds of marl, bioclastic limestone and sandstone with rare brachiopods in the northwestern part of the island. In the southwestern part of the island, Frasnian deposits comprise alternating grayish clay and siltstone with subordinate layers of sandstone and limestone. Kos'ko et al. (1985) suggest that the thickness of Frasnian deposits in the southern part of the island varies from 1 to $7.7 \mathrm{~km}$, however this great thickness is likely to be an overestimation due to repetition of the stratigraphy by faulting and folding. The fossils reported from the Frasnian deposits are mainly corals and brachiopods.

Famennian-lowermost Tournaisian deposits comprise 150-600 m of alternating sandstone and siltstone, locally with beds of argillite, conglomerate and limestone. The clastics are varicolored with units of redcolored continental sandstone. The beds of limestone locally contain brachiopods, corals, bryozoans, foraminifers and crinoids, while the sandstone and siltstone are generally unfossiliferous (Kos'ko et al., 1985) (Fig. 6).

1.3.1.1.2. Carboniferous. Lower Tournaisian-Serpukhovian strata are exposed along the west coast of Kotel'ny Island and are represented by up to $450 \mathrm{~m}$ of bioclastic, micritic and clayey limestone with subordinate beds of argillite. The limestone characteristically contains layers of chert nodules. Fossils are numerous and include brachiopods, crinoids, bivalves, corals and foraminifers. Lower Carboniferous deposits also have been described from sparse outcrops in the central part of the island, where $300-400 \mathrm{~m}$ of clayey and bioclastic limestone and argillite unconformably overlie Devonian, Ordovician or Silurian rocks.

Upper Carboniferous deposits typically are exposed locally in the western and southwestern parts of the island. They comprise siltstone, argillite, and sandstone with subordinate beds of conglomerate, breccia and limestone. In the northwestern and central part of Kotel'ny Island, Upper Carboniferous strata are up to $30 \mathrm{~m}$ thick and are represented by limestone and carbonate breccia with subordinate beds of sandstone and siltstone. Limestone contains a diverse suite of benthic fossils including brachiopods, trilobites and foraminifers (Fig. 6).

1.3.1.1.3. Permian. The Permian deposits of northwestern Kotel'ny Island comprise argillite with subordinate beds of siltstone and a few beds of limestone. Based on brachiopod biostratigraphy, the Lower Permian strata are $80 \mathrm{~m}$ thick, while Upper Permian strata are up to $100 \mathrm{~m}$ thick (Kos'ko et al., 1985). Permian strata display a facies transition from predominantly argillite in the northwest to limestone and calcareous argillite in the central part of the island. A decrease in thickness to $10-15 \mathrm{~m}$ also is observed in the same direction (Fig. 6).

1.3.1.2. Bel'kovsky Island. Deformed Devonian-Permian sedimentary strata are widely found across Bel'kovsky Island (Kos'ko et al., 1985, 2013; Kos'ko and Korago, 2009; Ershova et al., 2015c).

1.3.1.2.1. Devonian. The oldest rocks reported from Bel'kovsky Island are Middle Devonian (Eifelian-Givetian) carbonates (Kos'ko et al., 1985), represented by $600 \mathrm{~m}$ of massive and horizontally layered limestone with several beds of breccia and black bituminous and argillaceous limestone, which are variously dolomitized.

Frasnian, Famennian and Lower Tournaisian strata comprise mainly fine-grained turbidites, with numerous incised channels infilled with coarse-grained turbidites. The coarse-grained turbidites are represented by a set of graded beds with gravelly, rarely pebbly, conglomerate at the base (Ershova et al., 2015c). Olistostromes comprising bouldersize clasts of carbonate in a clayey matrix have been described throughout the succession. Olistoliths reaching up to a few hundred meters in diameter have been described in the western part of the island (Danukalova et al., 2014). These deposits have been dated from rare findings of conodonts, corals, ammonoids and brachiopods (Danukalova et al., 2014; Kos'ko et al., 1985; Nikolaeva et al., 2009). The estimated thickness of Upper Devonian-lowermost Carboniferous clastics is complicated by folding and thrusting, but may reach up to $3 \mathrm{~km}$ (Fig. 6).

1.3.1.2.2. Carboniferous-Permian. The youngest Paleozoic strata are also mainly represented by $400-500 \mathrm{~m}$ of fine-grained turbidites with a predominance of argillite and siltstone, while sandstone and conglomerate are rare. These deposits do not have a ubiquitous distribution across the island and the lower contact has not been clearly described. The strata were dated as Late Carboniferous using sparse palynological data (Kos'ko et al., 1985), however recent dating of detrital zircons (Ershova et al., 2015c) showed that the youngest grains are Early Permian in age, indicating that sedimentation continued significantly later than assumed previously.

1.3.1.3. Bol'shoy Lyakhovsky Island. Paleozoic strata crop out in the south and southeastern part of the island and comprise alternating sandstone and argillite up to $1300 \mathrm{~m}$ thick (Fig. 6). A Permian age has been identified based on spores described from the lower part of succession, however the upper part is unfossiliferous and could be post-Permian in age (Samusin and Belousov, 1985).

\subsubsection{Paleogeography}

The paleogeography of the New Siberian Islands during the Early Devonian can only be based on strata described from Kotel'ny Island, as deposits of this age are not exposed on the other islands within the archipelago. The alternation between limestone with diverse fossil assemblages, and dolomite with impoverished assemblages suggests that a shallow marine basin with a fluctuation between normal marine salinity and hypersaline conditions existed across Kotel'ny Island during the Lochkovian. An abundant and diverse benthic fauna suggests the establishment of a shallow marine basin with normal salinity during the Pragian-Emsian. The presence of abundant fragments of colonial corals suggests of the existence of carbonate reefs in the vicinity, although 

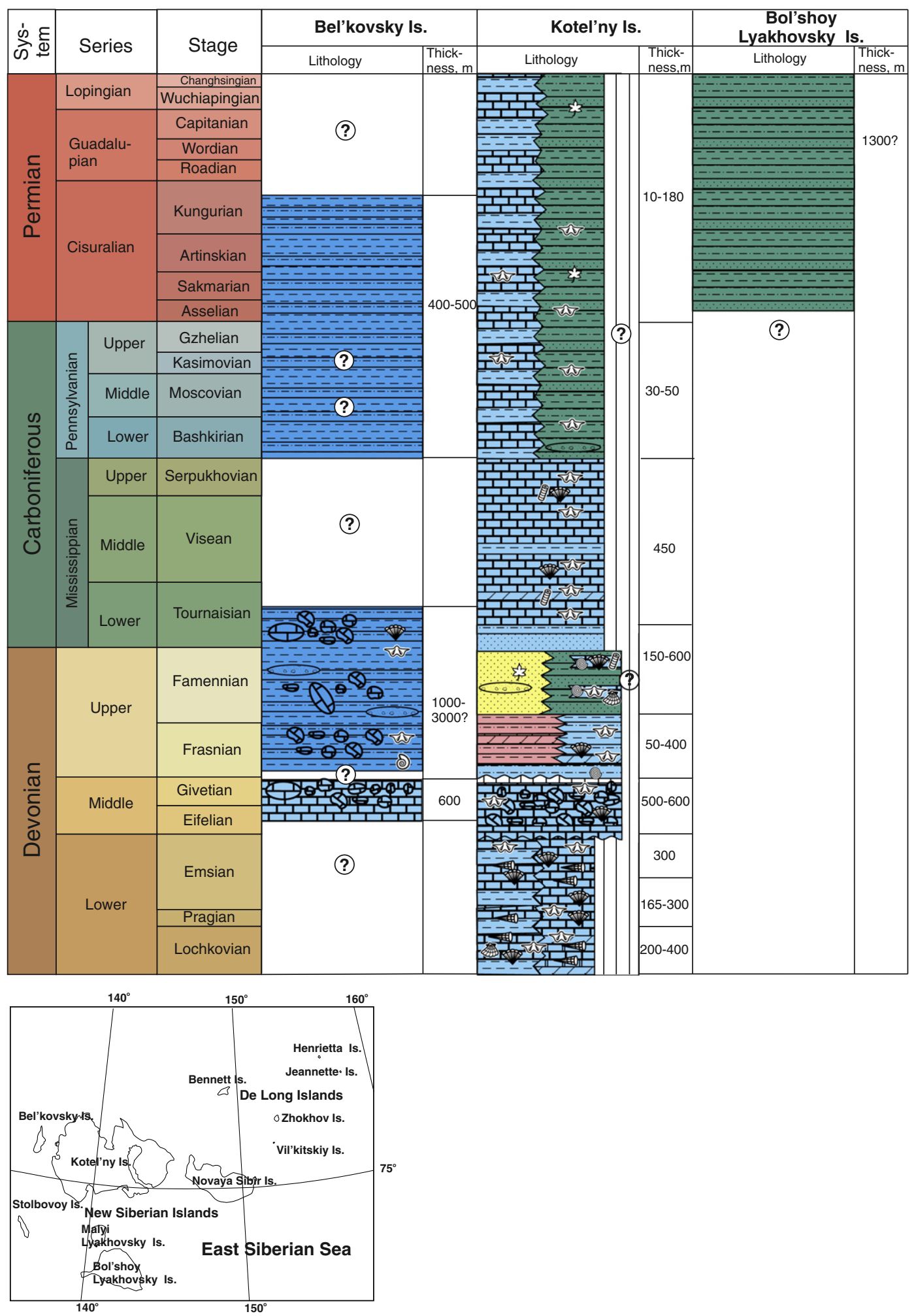

Fig. 6. Chronostratigraphic chart of Devonian-Permian deposits of New Siberian Islands (see legend on Fig. 2).

(Data sources: Danukalova et al., 2014; Ershova et al., 2015c; Cherkesova, 1972; Kos'ko et al., 1972, 1985, 2013; Kos'ko and Korago, 2009; Kuzmichev and Goldyrev, 2007; Nikolaeva et al., 2009; Prokopiev et al., 2015; Samusin and Belousov, 1985).

their location cannot be established. The presence of black organic-rich limestone beds within the Pragian-Emsian succession suggests that there were periods of restricted circulation within the basin, when anoxia developed at the sediment-water interface favoring the preservation of organic matter. The presence of a barrier reef complex could have enhanced restriction within the shallow basin thereby promoting the development of hypersaline environments during sea level lowstands in Lochkovian time, and restricted circulation within the basin during the Pragian-Emsian. A facies transition from bioclastic to micritic limestone occurred from north to south (present-day coordinates), possibly pointing to a deepening of the basin in that direction (Fig. 7). 


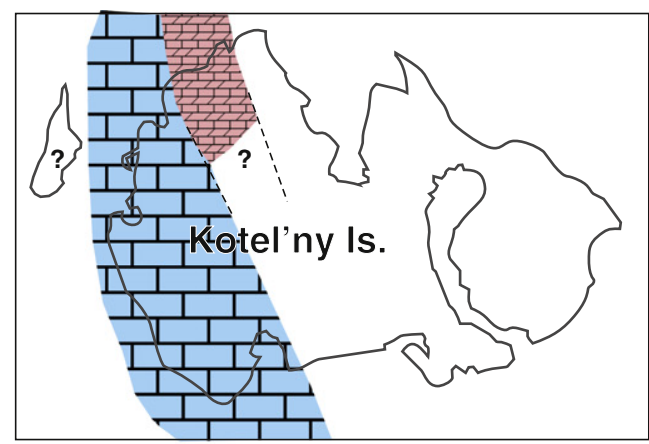

Early Lochkovian

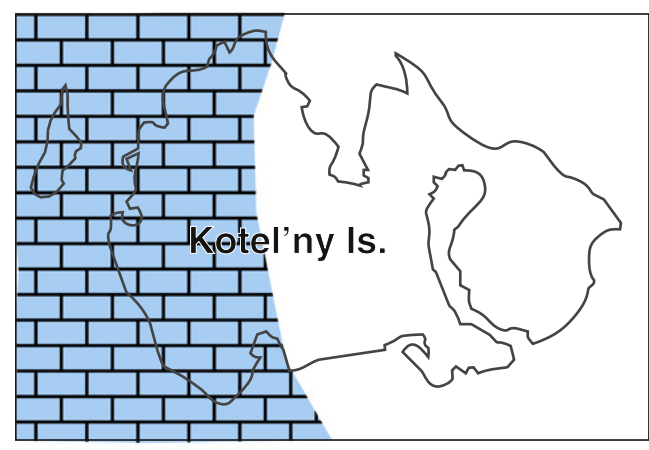

Early Eifelian

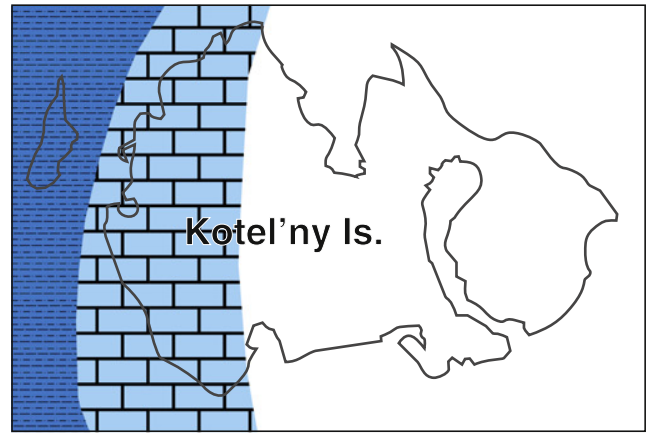

Early Visean

Legend
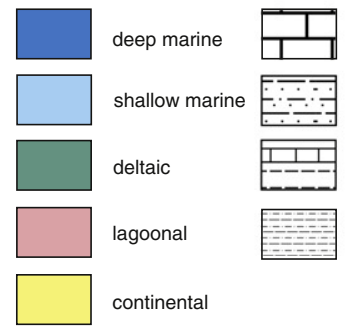

carbonates

alternation of argillite siltstone and sandstone

alternation of argillite,

siltstone and carbonate

alternation of argillite and siltstone

continental

Fig. 7. Paleogeographic maps for Devonian-Permian of Kotel'ny and Bel'kovsky islands (New Siberian Islands) (data sources as for Fig. 6).

The Middle Devonian deposits on both Kotel'ny and Bel'kovsky islands are characterized by a relatively thick succession of limestone with thick units of carbonate breccia. The breccia may have formed at the base of a carbonate escarpment, perhaps along the margin of a prominent barrier reef complex, which represented the main source of carbonate clasts. The Frasnian marked a sharp transition from mainly carbonate sedimentation, typical of the Early-Middle Devonian, to clastic sedimentation. Across Kotel'ny Island, marine siltstone and argillite locally with beds of limestone were deposited across the western part, while lagoonal and continental varicolored clastics are likely to have

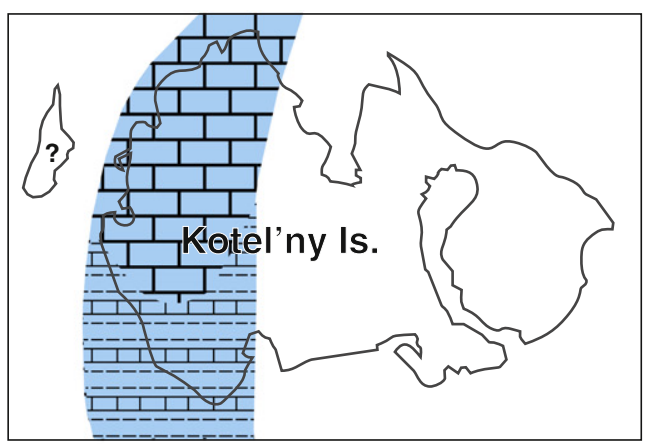

Early Emsian

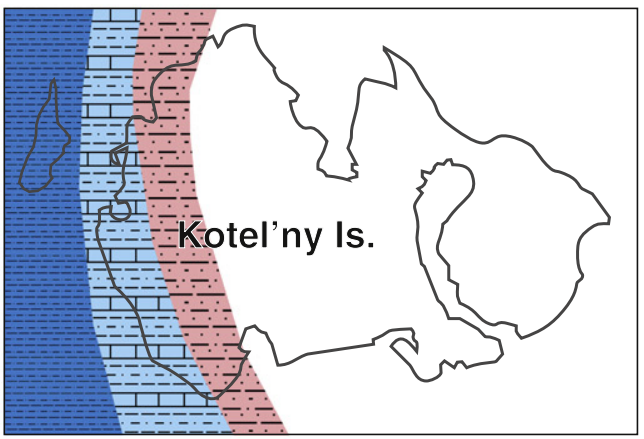

Early Frasnian

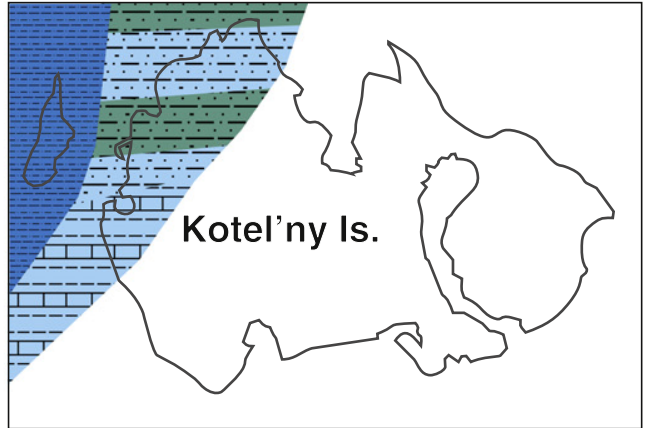

Late Carboniferous- Earliest Permian been deposited in the east. Deep marine turbidites were deposited across Bel'kovsky Island, signaling the onset of a tectonic event which led to the formation of a steep slope between Kotel'ny and Bel'kovsky islands. The Famennian to earliest Tournaisian deposits of Kotel'ny Island are represented by alluvial to deltaic clastics with rare limestone beds, while on Bel'kovsky Island turbidites with olistostromes were deposited. The Upper Tournaisian-Serpukhovian deposits of Kotel'ny Island consist of limestone with diverse benthic fossil assemblages, pointing to deposition in a shallow marine basin with normal marine salinity. Coeval deposits have not been described from Bel'kovsky Island, 
possibly due to rare fossil occurrences within the thick turbidite succession and very complicated geological structure due to Mesozoic folding and thrusting. Upper Carboniferous rocks across Kotel'ny Island are represented by shallow marine carbonates along with deltaic and shelf clastic successions, which are poorly correlated across the island due to patchy distribution. Turbidites continued to be deposited in a deep marine environment across Bel'kovsky Island. A similar facies zonation persisted into the Permian, with shallow marine clastics in the northwestern part and carbonates deposited in the central and southwestern part of the Kotel'ny Island and deep marine turbidites across Bel'kovsky Island (Fig. 7).

\subsection{Chukotka and Wrangel Island}

Devonian-Permian strata of Chukotka and Wrangel Island are highly deformed, intruded by Paleozoic and Mesozoic magmatic rocks, metamorphosed to various grade, and exposed only locally. These factors lead to difficulties with subdivision and correlation of strata across the region (Fig. 8).

\subsubsection{Stratigraphy}

1.4.1.1. Wrangel Island. Devonian-Permian deposits crop out across a belt stretching from the northwestern part to the central part of the island. The stratigraphic position of the sedimentary units is based on poorly preserved fossils and structural relationships, therefore the age constraints on the upper Paleozoic sequence are not very precise (Fig. 8).

1.4.1.1.1. Devonian. The oldest Devonian rocks have been described from the western and northwestern parts of Wrangel Island and are represented by two distinct clastic and carbonate successions. The clastic sequence is up to $700 \mathrm{~m}$ thick and described from Dremkhed Mountain in the northern part of the island (Kos'ko et al., 2003), where it is represented by intercalating sandstone, siltstone and argillite with rare limestone beds containing brachiopod fragments. The main carbonate succession exposes in the northwest of the island along the Gusinaya River. It comprises a 400-500 m-thick sequence of alternating limestone, dolomite and subordinate clastic beds, each typically 10$50 \mathrm{~m}$ thick. The limestone is bioclastic and contain brachiopods, bryozoans, corals and crinoids (Kos'ko et al., 2003). The fossils reported from these deposits have resulted in a broad Silurian-Early Devonian age assignment (Kos'ko et al., 2003). The rest of the Devonian succession unconformably overlies the Silurian-Lower Devonian and older deposits. The succession described from the western part of the islands includes a basal unit of gravelly to bouldery polymictic conglomerate. Conglomerate clasts include foliated and gneissic lithologies demonstrating an earlier tectonic event (Kos'ko et al., 1993). The middle part of the succession comprises sandstone and metasandstone with subordinate beds of siltstone and argillite, while siltstone and sandstone comprise much of the upper part. In the central part of the island, alternating sandstone, argillite and siltstone with rare beds of bioclastic limestone have been described from a few scattered localities. The age of the succession has been identified based on sparse Givetian brachiopods and Frasnian foraminifers as Middle-Late Devonian (Kos'ko et al., 2003). The thickness of the Middle-Upper Devonian rocks varies significantly from 500 to $1200 \mathrm{~m}$ (Fig. 8).

1.4.1.1.2. Carboniferous. Lower Carboniferous strata are represented by a $350 \mathrm{~m}$-thick succession of intercalating clastics, carbonates, evaporites and volcanic rocks, with a basal conglomerate that unconformably overlie Devonian strata (Vasil'eva and Solovieva, 1979). The lower part of the succession reported from the central part of the island (Khishchnikov River) is represented mainly by sandstone with subordinate beds of siltstone and argillite, varying in thickness from 60 to $150 \mathrm{~m}$ (Bondarenko et al., 2014; Ivanov, 1973; Kos'ko et al., 1993, 2003). This lower unit is overlain by a $200 \mathrm{~m}$-thick succession of carbonates comprising alternating dolomite and limestone with subordinate gypsum beds. A 100-200 m-thick effusive volcanic unit has been reported from the Neizvestnaya River (central part of the island) is to be Early Carboniferous in age based on its stratigraphic position beneath welldated Upper Carboniferous marine strata. Across the western part of the island, a few hundred meters thick mainly clastic succession is exposed, comprising conglomerate, sandstone and argillite with subordinate beds of gypsum. The age of deposits has been identified based on rare corals and brachiopods as Late Tournaisian-Visean.

The Lower Carboniferous is unconformably overlain by upper Lower-Upper Carboniferous deposits, which differ significantly in sedimentary facies between the southern and northern parts of the island. In the south, the deposits are represented by $1400-1500 \mathrm{~m}$ of dark gray micritic and bioclastic limestone with subordinate beds of limy argillite in the lower part of succession, while argillite become more abundant in the upper part. In the northern and western part of the island, 300-500 m of massive carbonate bioherms and bioclastic limestone with beds of sandstone, and gravelly to pebbly conglomerate have been reported. Fossils found in scattered locations have led to a Tournaisian-Moscovian age assignment. According to Bondarenko et al. (2014), this succession unconformably overlies Visean deposits, so could be considered as Serpukhovian-Late Carboniferous.

1.4.1.1.3. Permian. The thickness and facies of Permian strata differs in the south and north of Wrangel Island (Kameneva and Chernyak, 1975). In the south, they lie conformably on the Upper Carboniferous strata and, in the north they lie unconformably on the older rocks. The Permian succession in the southeastern part of the Island (Khishchnikov River) is represented by $250 \mathrm{~m}$-thick argillite with rare beds of gravelly conglomerate. The middle part of the succession comprises thinly bedded limestone and argillite up to $140 \mathrm{~m}$ thick, while the upper part is $400 \mathrm{~m}$ thick and represented by argillite with subordinate beds of sandstone. Argillite with cherts occur at the top of succession (Kos'ko et al., 2003) in the easternmost outcrops. In the southwest of the island, carbonates become more abundant within the lower part of the Permian succession. A different sedimentary succession has been described from the northern part of the island, where the Permian is roughly represented by three sedimentary units. The 160 m-thick lower unit comprises polymictic conglomerate with pebbly to bouldery clasts (up to $2 \times 10 \mathrm{~m}$ ). The clasts are very diverse in composition, comprising quartz, granites, Silurian limestone, argillite, schists and bioclastic limestone. The 300 m-thick middle unit mainly consists of micritic, bioclastic and clayey limestone with subordinate beds of sandstone, with abundant brachiopod and gastropod shells found within the limestone. The upper unit (560 m thick) is represented by alternating argillite and limestone with subordinate beds of calcareous sandstone and sandy limestone. The Permian deposits in the northern part of Wrangel Island are estimated to be up to $1200 \mathrm{~m}$ thick (Fig. 8) (Kos'ko et al., 2003). Their Permian age has been substantiated by rare well-preserved Early Permian foraminifers and Late Permian brachiopods.

1.4.1.2. Chukotka. Devonian to Permian strata of Chukotka are regionally deformed and metamorphosed. The degree of deformation and grade of metamorphism generally increase with stratigraphic age and structural depth in the section (Miller and Verzhbitsky, 2009). The best preserved sedimentary successions are located along the coast, while the grade of metamorphism increases southward towards the South Anyui suture making identification of both fossils and the initial composition of rocks difficult.

1.4.1.2.1. Western Chukotka

1.4.1.2.1.1. Devonian. Lower Devonian strata crop out along the Long Strait and in the Kuul'Innukay and Kus'veem rivers, comprising sandstone and argillaceous to silty phyllite, with subordinate beds of limestone and calcareous argillite (Rogozov and Vasilieva, 1968; Shaposhnikov et al., 1999). The lower part of the succession is mainly represented by sandstone interbedded with argillite and rare beds of limestone, while the upper part comprises mainly siltstone. The strata have been dated using brachiopods, foraminifers, corals, tentaculites 

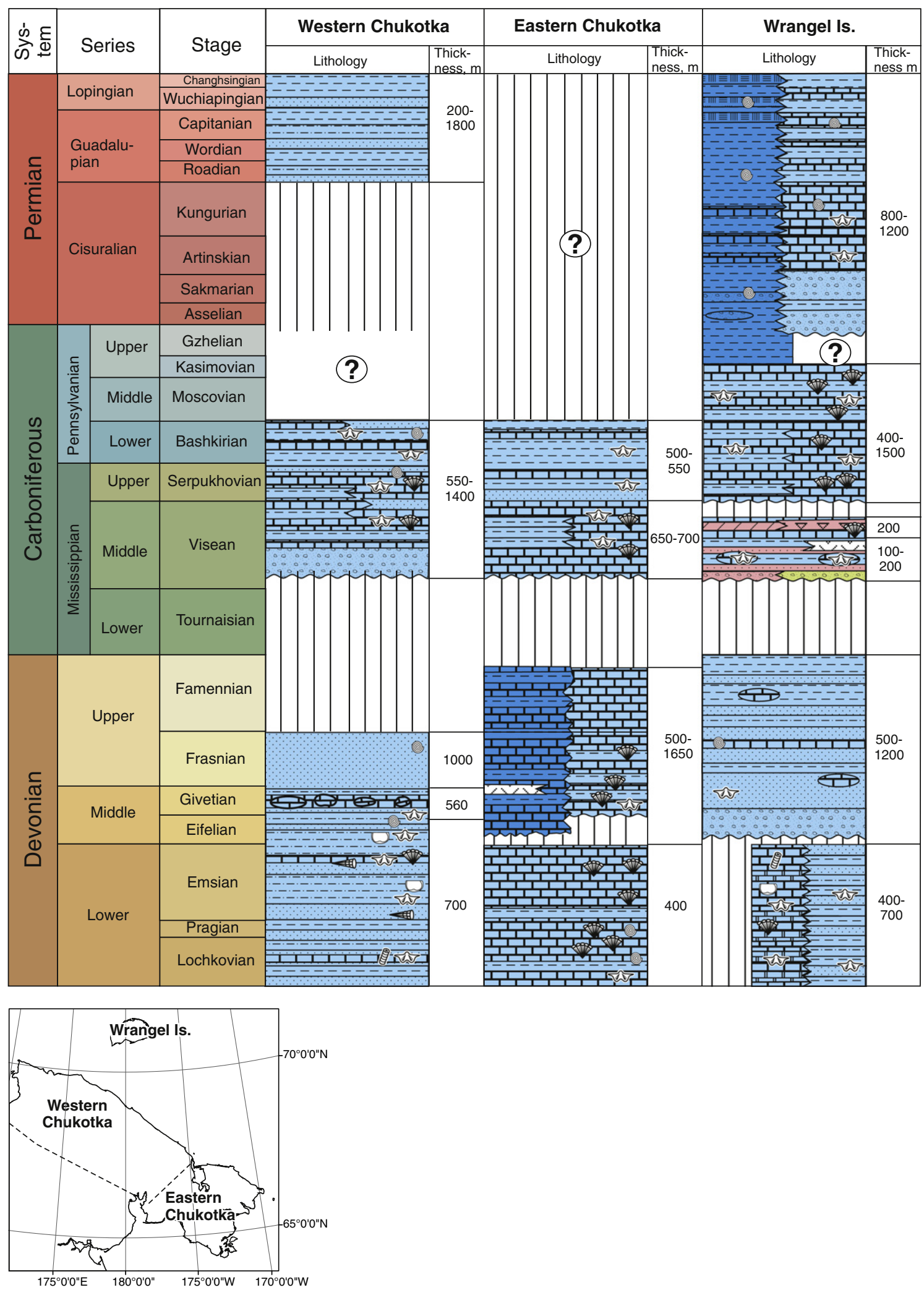

Fig. 8. Chronostratigraphic chart of Devonian-Permian deposits of Chukotka and Wrangel Island (see legend on Fig. 2).

(Data sources: Bondarenko et al., 2014; Cecile et al., 1991; Kameneva and Chernyak, 1975; Kos'ko et al., 1990, 1993, 2003; Natal'in et al., 1999; Rogozov and Vasilieva, 1968; Samorukov and Matvienko, 1984; Shaposhnikov et al., 1999; Tuchkova et al., 2014; Verzhbitsky et al., 2015; Vladimirtseva et al., 2001).

and trilobites as Early Devonian-earliest Middle Devonian in age, with an estimated thickness of about $700 \mathrm{~m}$ (Rogozov and Vasilieva, 1968). The Middle Devonian lies conformably on older strata and comprises a
560 m-thick succession of alternating siltstone and sandstone, containing beds of carbonate breccia with rare remnants of brachiopods (Rogozov and Vasilieva, 1968). The Upper Devonian rocks comprise 

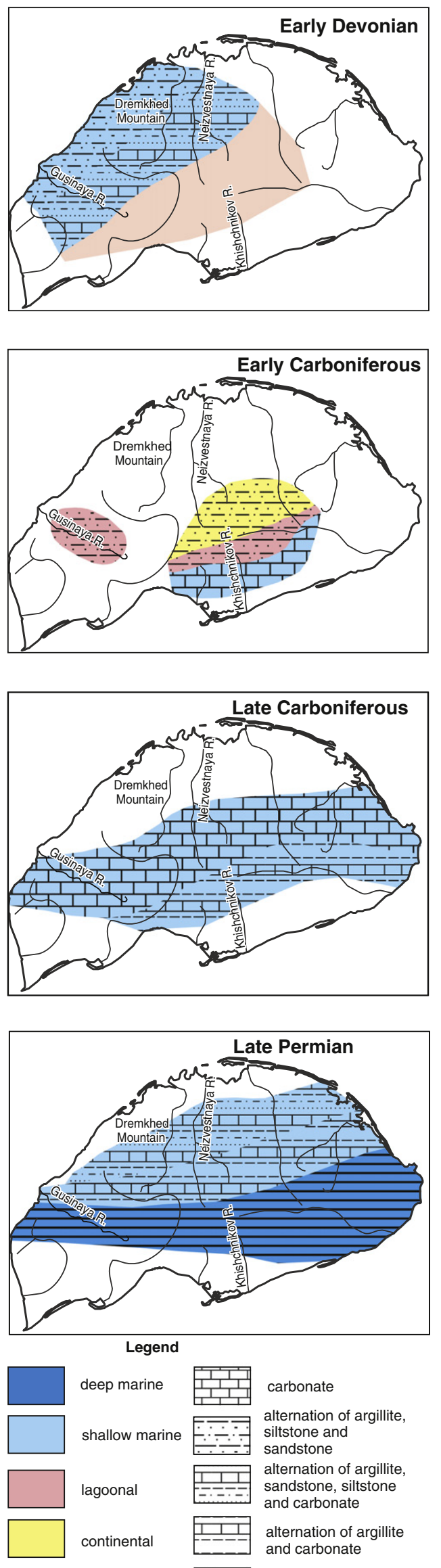

carbonate

alternation of argillite, siltstone and sandstone

alternation of argillite, sandstone, siltstone and carbonate

alternation of argillite and carbonate

argillite
$800-1000 \mathrm{~m}$ of sandstone with rare beds of argillite (Fig. 8). These strata have been dated as Frasnian in age based on foraminifera biostratigraphy (Shaposhnikov et al., 1999).

1.4.1.2.1.2. Carboniferous. A succession of interbedded conglomerate, limestone, limy siltstone and argillite dated as Lower-lowermost Upper Carboniferous unconformably overlies Upper Devonian strata (Fig. 8). The composition and thickness of Carboniferous rocks varies significantly across western Chukotka. Conglomerate beds have been described from the base of the succession and comprise pebbly to bouldery polymictic conglomerate with clasts of granite, diorite, quartz and quartzite. The rest of the Carboniferous succession is characterized by significant lateral facies changes and is represented by alternating limestone, siltstone, argillite and sandstone, causing great difficulties in correlating beds across the area (Samorukov and Matvienko, 1984). The limestone contain a diverse range of marine fossils, including corals, brachiopods, crinoids and foraminifera, allowing the succession to be dated as Visean-Bashkirian. The thickness of Carboniferous deposits varies from 550 to $1400 \mathrm{~m}$ across western Chukotka (Shaposhnikov et al., 1999).

1.4.1.2.1.3. Permian. Permian deposits have a very limited distribution and are represented by $250-1800 \mathrm{~m}$ of intercalated sandstone, siltstone and argillite (Fig. 8) (Tuchkova et al., 2014). The age of these deposits is poorly constrained and based on poorly preserved plant fossils (Samorukov and Matvienko, 1984).

1.4.1.2.2. Eastern Chukotka. Devonian-Permian deposits have been reported from a few separated tectonic blocks across eastern Chukotka. Contact metamorphism of upper Paleozoic strata associated with Mesozoic volcanism renders identification of original facies, correlation and age determination extremely difficult across the region (Natal'in et al., 1999; Vladimirtseva et al., 2001).

1.4.1.2.2.1. Devonian. The lowest metamorphic grades have been described along the Chukotka Sea coast in the northeastern part of the region (near the mouth of the Chegitun River). Lower Devonian deposits outcrop here in a few tectonic blocks and comprise bituminous and clayey limestone, coralline limestone, limy argillite and dolomite, with a thickness of up to $400 \mathrm{~m}$. They conformably lie on Upper Silurian deposits (Natal'in et al., 1999). A broad Early Devonian age has been assigned to the strata based on rare foraminifers (Vladimirtseva et al., 2001).

Middle Devonian-Frasnian strata lie unconformably on Lower Devonian deposits. Vladimirtseva et al. (2001) divided Middle DevonianFrasnian strata along the Chukchi Sea coast into a number of units. The lower unit is represented by a 120-130 m-thick succession of bioclastic limestone with subordinate beds of siliceous and calcareous argillite. Based on rare brachiopods, a Givetian age has been assigned to this unit (Vladimirtseva et al., 2001). The second unit comprises $50 \mathrm{~m}$-thick argillite overlain by $20 \mathrm{~m}$-thick coralline limestone, dated as Late Givetian-Frasnian in age based on corals and conodonts. The upper unit consists of $220 \mathrm{~m}$ of interbedded micritic limestone and argillite, containing Frasnian and possibly Famennian conodonts. Natal'in et al. (1999) described the Middle-Upper Devonian strata of northeastern part of the Chukotka (Chegitun River) as a succession of thinly bedded turbidites comprise metacarbonates and phyllites, reaching up to $800 \mathrm{~m}$ in thickness. Natal'in et al. (1999) described 2to 35-m-thick units of andesitic tuff within the Middle Devonian succession. Upper Givetian-Frasnian deposits have been reported from the Bering Sea coast of eastern Chukotka, where they comprise up to $1650 \mathrm{~m}$ of interbedded metamorphosed limestone and argillite (Fig. 8).

1.4.1.2.2.2. Carboniferous. Visean limestone and argillite represent the base of the Carboniferous succession in eastern Chukotka, suggesting that the Tournaisian stage is missing in this area. Limestone predominates in the lower part of the Visean section, grading upward into an

Fig. 9. Paleogeographic maps for Devonian-Permian of Wrangel Island (after Kos'ko et al. 2003, modified). 

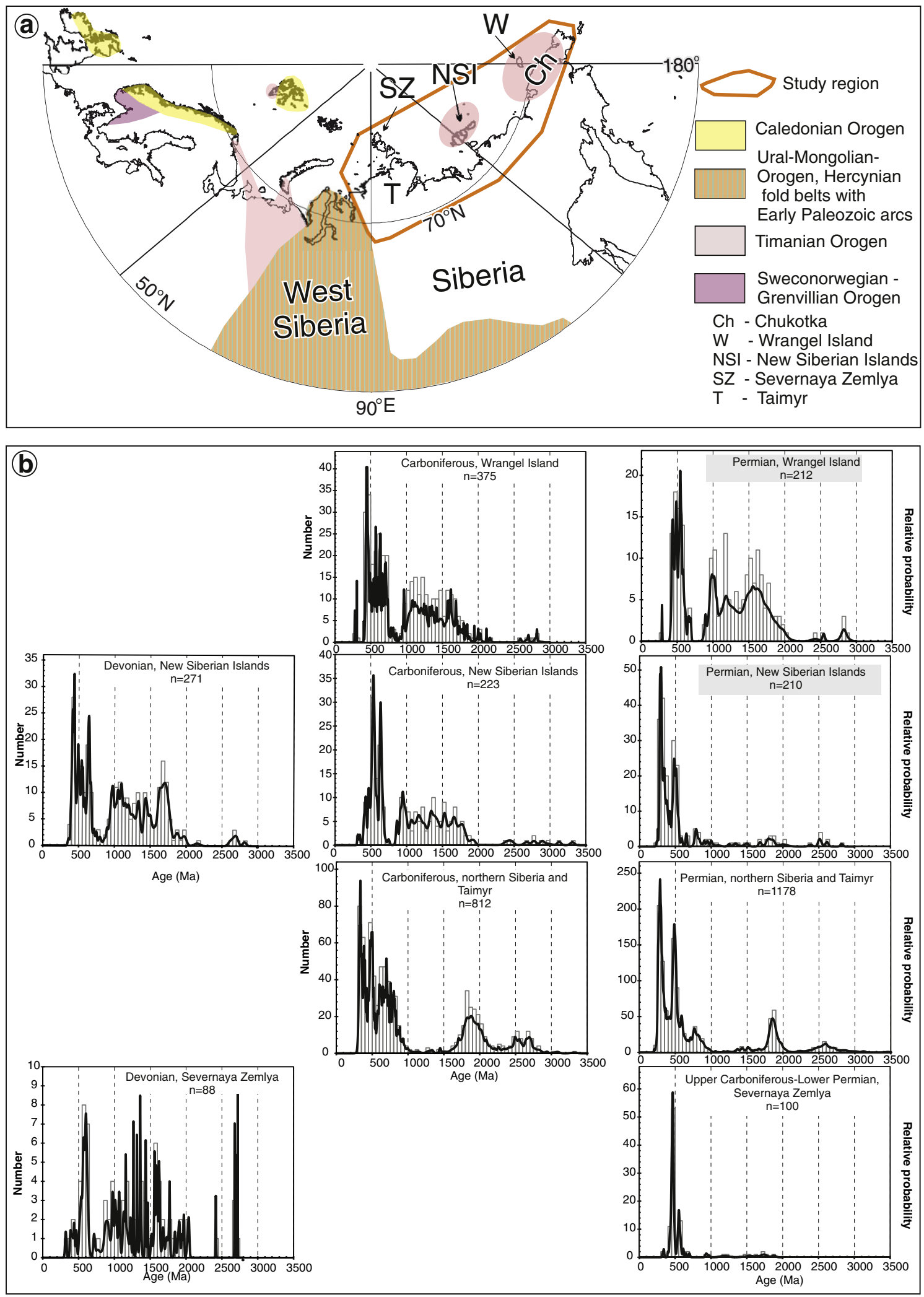

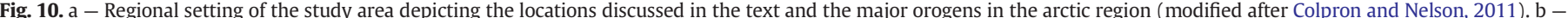

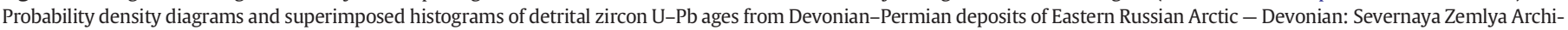

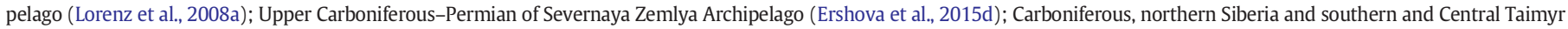

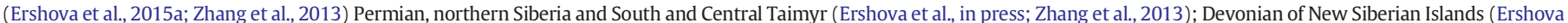

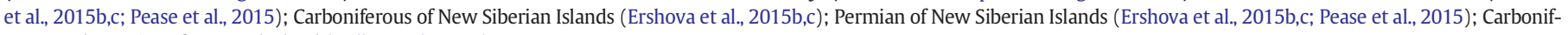
erous and Permian of Wrangel Island (Miller et al., 2010). 


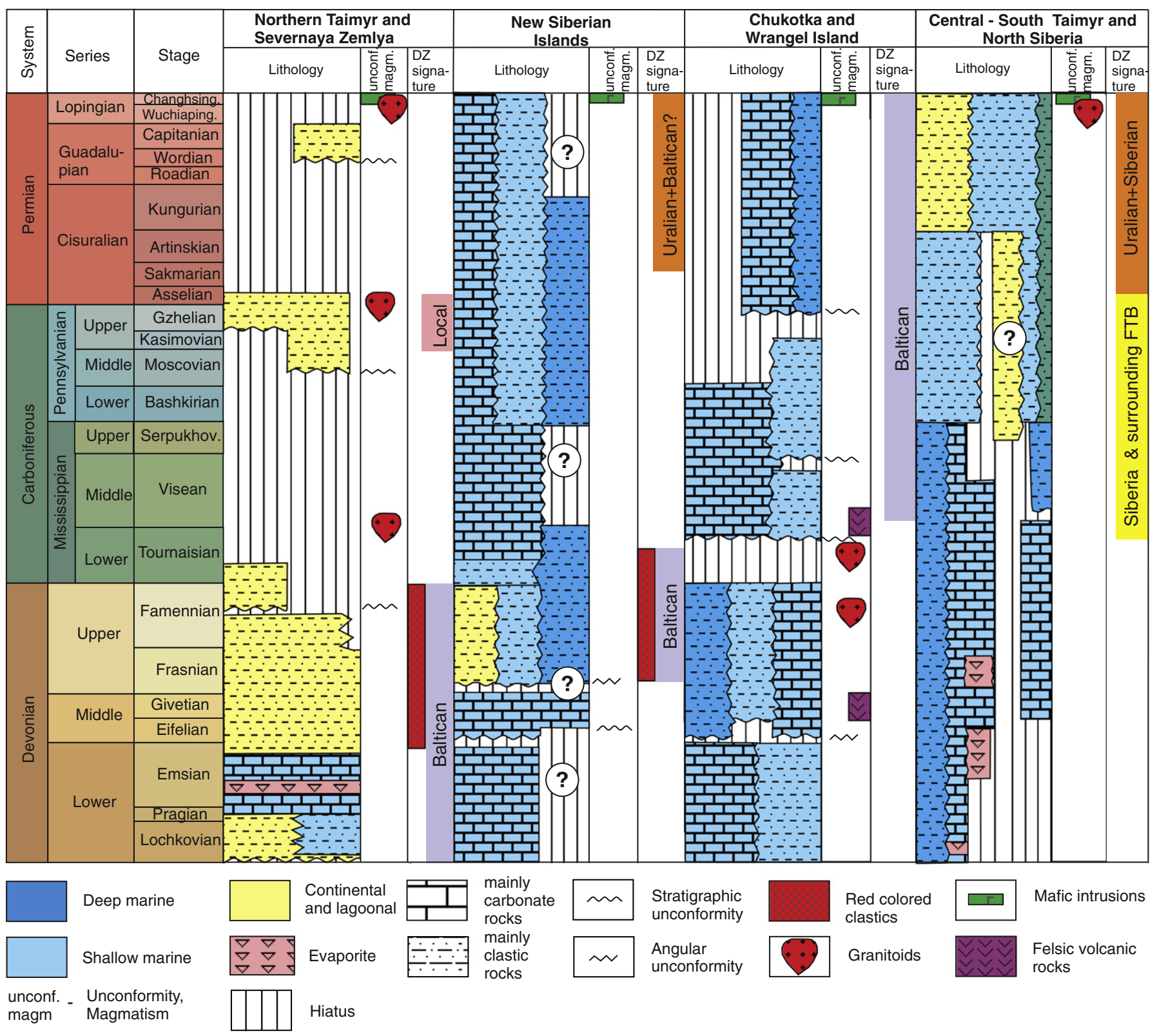

Fig. 11. Summary chart of tectonostratigraphy for the Eastern Russian Arctic. For data sources see references on Figs. 2, 4, 6, 8 and 10.

increasingly argillaceous sequence, with a total thickness of up to 650$700 \mathrm{~m}$. Serpukhovian-Bashkirian strata are represented by sandstone with beds of siltstone at the base (up to $100 \mathrm{~m}$ thick), grading upward to interbedded argillite and limestone (400-450 m thick). Exposures of Permian strata have not been identified in eastern Chukotka, but Sokolov et al. (2014) suggested the presence of Permian rocks based on the presence of Late Permian inherited zircons in the gabbro intrusion in Kolyuchinskaya Bay.

\subsubsection{Paleogeography}

The interpretation of depositional environments is quite difficult across the Chukotka-Wrangel area due to the very scattered distribution of Paleozoic rocks, lack of good stratigraphic control and intensive metamorphism and deformation of deposits.

1.4.2.1. Wrangel Island. The Upper Silurian to Lower Devonian strata of Wrangel Island represent two different successions. The first is found in the western part of the island and mainly comprises shallow marine carbonates, grading into a clastic succession towards the north.
According to Kos'ko et al. (1993, 2003), both the clastic and carbonate successions have been interpreted as relatively shallow-marine deposits (Fig. 9). Upper Silurian-Lower Devonian strata are missing through erosion or non-deposition in the central part of the island. The rest of the Devonian succession lies unconformably on Silurian-Devonian deposits and older rocks. The recent studies by Verzhbitsky et al. (2015) revealed different structural styles between the Devonian-Triassic and older Silurian-Lower Devonian successions, suggesting the presence of an angular unconformity at the top of the Silurian-Lower Devonian unit. There are controversial interpretations of depositional environments in the uppermost Lower Devonian-Upper Devonian succession of Wrangel Island. Kos'ko et al. (1993) assumed that the environmental setting could be characterized as shallow marine, with marine transgression eventually covering the central part of Wrangel Island. According to Kos'ko et al. (2003), the uppermost Lower-Upper Devonian strata have been interpreted as a flysch succession deposited in a continental slope environment. However, the formations directly above and below were deposited in relatively shallow water environments, therefore it is most likely that these strata are also a shallow water 
succession. Cecile et al. (1991) claimed that the Devonian strata across Wrangel Island were deposited within a fluvial and coastal marine setting.

The Tournaisian stage is missing across Chukotka and reported with great uncertainty from Wrangel Island. The deposition of the Upper Tournaisian (?)-Visean deposits of Wrangel Island coincided with eruption of rift related bimodal magmatic rocks (Kos'ko et al., 2003; Verzhbitsky et al., 2015). The presence of a relatively thick conglomerate unit with clasts derived from erosion of underlying rocks at the base points to development of local erosional uplifts and depressions with mainly continental to shallow marine environments (Fig. 9). The overlying intercalating carbonates and dolomite with beds of evaporites were deposited in lagoonal to shallow marine environments.

The overlying Visean-Upper Carboniferous deposits of Wrangel Island are represented by a mainly carbonate succession, suggesting marine transgression across the entire island. The carbonate bioherms and bioclastic limestone deposited in the northern part of the island are replaced southward by micritic and clayey limestone, suggesting a deepening of the basin towards the south. The Lower-Upper Carboniferous succession demonstrates fining- and deepening-upward sedimentary trends (Kos'ko et al., 2003). Similar successions of approximately the same age are found throughout Chukotka and possibly deposited in similar environments.

The Permian deposits of Wrangel Island start with the accumulation of a relatively thick succession of polymictic conglomerate in the north, grading to interbedded argillite and conglomeratic beds towards the south. This sedimentary unit marks the formation of local uplifts which sourced clastics into the basin. The middle part of the Permian succession is represented by shallow-water carbonate in the northwest and a coeval deeper water succession of argillite, limestone and chert in the southeast, pointing to a deepening of the basin in that direction (Fig. 9) (Kos'ko et al., 2003).

1.4.2.2. Chukotka. The Lower Devonian deposits of western Chukotka are mainly clastics with subordinate beds of limestone, while in eastern Chukotka coeval strata are mainly carbonates. Marine benthic fossils have been reported from both successions, suggesting a shallow marine environment of deposition. A marine depositional environment has been interpreted for the Middle-Upper Devonian succession of western Chukotka based on the presence of marine benthic fossils (Shaposhnikov et al., 1999). In eastern Chukotka, disparate tectonic blocks contain Middle Upper Devonian shallow marine carbonates (Vladimirtseva et al., 2001) and carbonate turbidites (Natal'in et al., 1999). The Lower Carboniferous succession of eastern Chukotka is similar to that in the neighboring Wrangel Island and possibly deposited in similar continental to shallow marine environments. The Visean strata of western Chukotka are mainly massive carbonates deposited in a shallow marine basin (Shaposhnikov et al., 1999). In western northern Chukotka, an undivided succession of sandy and coaly argillite is assumed to be Late Permian in age, which was possibly deposited in a shelf environment (Tuchkova et al., 2014).

\subsection{Overview of provenance studies}

A number of $\mathrm{U}-\mathrm{Pb}$ detrital zircon studies recently have been conducted on Paleozoic successions of the Eastern Russian Arctic. The available dataset covers the Devonian-Permian stratigraphy of Severnaya Zemlya and the New Siberian Islands, Carboniferous-Permian of northern Siberia, and Carboniferous-Permian of Wrangel Island (Ershova et al., 2013, 2015a,b,c,d; Lorenz et al., 2008a; Miller et al., 2010; Pease et al., 2015; Prokopiev et al., 2013; Zhang et al., 2013). There are no published detrital zircon data from the Devonian-Permian deposits of the Chukotka Peninsula to date. We constructed relative probability plots (Fig. 10) for studied localities across the Eastern Russian Arctic. The data displayed in Fig. 10 suggest that the Devonian-Carboniferous clastic rocks of the New Siberian Islands, Severnaya Zemlya and Wrangel
Island were derived from the same provenance, while the Carboniferous clastics of northern Siberia were derived from a different source area. Carboniferous clastics deposited across northern Siberia were potentially derived from multiple provenance areas. The Devonian-Carboniferous strata of the New Siberian Islands, Devonian of Severnaya Zemlya, and Carboniferous of Wrangel Island contain major peaks attributed to Grenvillian (ranging from 970 to $1000 \mathrm{Ma}$ ), Timanian (ranging from 540 to $630 \mathrm{Ma}$ ) and Caledonian (ranging from 415 to $485 \mathrm{Ma}$ ) detrital zircon ages, implying a possible clastic source from the northern margin of Baltica-Laurentia during the middle-late Paleozoic (Ershova et al., 2015b,c; Miller et al., 2010).

The detrital zircon data from Carboniferous strata of northern Siberia suggest that the Lower Visean clastic rocks were derived from a proximal provenance composed of Siberian Craton basement and its overlying sedimentary cover, while Upper Visean-Upper Carboniferous clastics are likely to have been derived from the Taimyr-Severnaya Zemlya Orogenic Belt (Kara Terrane), with additional sediment contributions from the southwestern margin of Siberia (Ershova et al., 2013, 2015a; Prokopiev et al., 2013).

The distribution of detrital zircons within the Permian deposits is very different from that in older strata across the New Siberian Islands (Fig. 10), with an abundance of ages close to the age of sedimentation, which can be attributed to a provenance within the developing Uralian Orogen (Ershova et al., 2015b,c; Pease et al., 2015). The Permian sedimentary successions of the Eastern Russian Arctic show differing patterns in detrital zircon age populations in areas from which detrital zircons data are included in Fig. 10. The U-Pb dating of detrital zircons from the Upper Carboniferous-Lower Permian sandstone of the Severnaya Zemlya Archipelago (Bol'shevik Island) reveals a predominance of Early-Middle Ordovician zircons, with no grains close to the age of sedimentation, indicating that these sandstone were derived locally from neighboring Lower Ordovician magmatic rocks (Ershova et al., 2015d). The zircon age populations from the Permian deposits of Wrangel Island suggest that the clastic sediment was continuously sourced from the Baltican provenance throughout Carboniferous and Permian time (Miller et al., 2010), or from reworking of the Devonian-Carboniferous deposits.

The detrital zircon populations obtained from the Permian clastics of northern Siberia are characterized by large percentages of late Paleozoic and early Paleozoic zircons, which precise ages can be correlated with magmatic events known from the Ural-Mongolian Orogen. This correlation suggests that these clastics were mainly sourced from areas located to the west and southwest of the Siberian Craton (in present-day coordinates), with an additional sediment contribution from the reworked sedimentary cover and basement of Siberia (Ershova et al., in this issue, and references therein).

\section{Summary}

Our compilation of the available stratigraphic, paleogeographic, and provenance data, accompanied by data on the middle-late Paleozoic magmatic activity across the Eastern Russian Arctic, is summarized in Fig. 11. There are a number of differing paleo-tectonic models for the locations of the continental blocks now comprising the New Siberian Islands, Severnaya Zemlya, Chukotka and Wrangel Island, prior to opening of the Mesozoic and Cenozoic Arctic Ocean basins. These models consider that the New Siberian Islands were either attached to Siberia (Danukalova et al., 2014; Metelkin et al., 2014 and references therein), or to Laurentia-Baltica (Ershova et al., 2015b,c). Lorenz et al. (2008a) considered that the Severnaya Zemlya Archipelago continental block represented the marginal part of Baltica, while Metelkin et al. (2005) considered it as a separate micro-continental terrane throughout the early-earliest late Paleozoic, before accreting to Siberia during the Carboniferous. Chukotka and Wrangel Island have been classically interpreted as a part of the composite Arctic Alaska-Chukotka Microplate (Miller et al., 2010; Natal'in et al., 1999). On the other hand, 
Zonenshain et al. (1990) considered the Severnaya Zemlya Archipelago, New Siberian Islands, Chukotka and Wrangel Island to collectively represent a portion of a large hypothetical continent termed "Arctida", which occupied much of the Eastern Russian Arctic shelf.

Based on stratigraphic correlations, facies transitions and detrital zircon data, two groups of middle-late Paleozoic basins sharing a common geological history are recognized within the eastern part of the Russian Arctic (Fig. 11): (1) New Siberian Islands, Severnaya Zemlya Archipelago, Chukotka and Wrangel Island, and (2) northern Siberia including South-Central Taimyr.

The Devonian-Carboniferous sedimentary succession of the New Siberian Islands, Severnaya Zemlya, Chukotka and Wrangel Island is mainly represented by shallow marine to lagoonal deposits, with the presence of deep water facies along the periphery of the continental blocks. The transition from shallow marine to deeper water deposits (in a western direction in present-day coordinates) occurred across the New Siberian Islands, with turbidites deposited across the westernmost island, Bel'kovsky, throughout Late Devonian-Permian time. Natal'in et al. (1999) interpreted the Middle-Late Devonian rocks of northeastern Chukotka as a turbidite succession; therefore a deepening of the basin towards the southeast (present-day coordinates) could be predicted across the Chukotka and Wrangel area. Across the Severnaya Zemlya Archipelago, the Devonian-Carboniferous succession mainly consists of shallow marine to continental deposits, with a relative deepening of the basin towards the northwest (in present-day coordinates). In summary, the Devonian-Carboniferous successions of the New Siberian Islands, Chukotka and Wrangel Island represent shallow marine deposits, while shallow marine to continental environments prevailed across Severnaya Zemlya. The characteristic feature of the MiddleUpper Devonian deposits of Severnaya Zemlya is the presence of clastic red beds, which have been interpreted as the deposits of a Caledonian foreland basin (Lorenz et al., 2008a). Upper Devonian-lowermost Carboniferous red-colored continental to shallow marine sandstone and siltstone also have been reported from Kotel'ny Island, along with an almost identical distribution of detrital zircon age populations (Ershova et al., 2015b) (Fig. 11), suggesting that the New Siberian Islands may have represented a distal part of the Caledonian foreland in the Late Devonian-earliest Carboniferous. Paleozoic detrital zircons are also abundant in the Carboniferous rocks of Wrangel Island (Miller et al., 2010), suggesting a possible Caledonian source for the clastics as well. The common affinity of the New Siberian Islands, Severnaya Zemlya, Chukotka and Arctic Alaska in the Early Paleozoic, and their periBaltican-Laurentian affinity, is also supported by detrital zircon data (Ershova et al., in press) and microfossil assemblages (Dumoulin et al., 2002).

There are a few episodes of middle-late Paleozoic magmatism reported across the Eastern Russian Arctic, which can help to identify episodes of terrane accretion and tectonic activity. These include earliest Carboniferous granites described from northern Taimyr and Severnaya Zemlya (Kara Terrane) (Lorenz et al., 2007; Makariev, 2013), roughly coeval granites reported from Chukotka (Lane et al., 2015; Katkov et al., 2013; Luchitskaya et al., 2015), and slightly younger felsic volcanic rocks studied on Wrangel Island. Late Devonian granites have been reported from a few localities in Chukotka (Amato et al., 2014; Natal'in et al., 1999). These Late Devonian-Early Carboniferous magmatic rocks of Chukotka have been interpreted as having formed in arcback-arc settings (Amato et al., 2014; Luchitskaya et al., 2015). The Early Carboniferous granites of Severnaya Zemlya and northern Taimyr (Kara Terrane) have been interpreted as evidence for the time of collision between the Kara Terrane and Siberia (Ershova et al., 2013; Prokopiev et al., 2013). Several unconformities have been reported from the Devonian-Carboniferous successions of Severnaya Zemlya, New Siberian Islands, Chukotka and Wrangel Island, but these are mainly interpreted to reflect fluctuations in eustatic sea level, resulting in periods of subaerial exposure and erosion of older rocks. A few angular unconformities have been reported from Wrangel Island and the New
Siberian Islands between different units of the Middle-Upper Devonian succession, and these unconformities have been correlated with the Ellesmerian Orogeny (Prokopiev et al., 2015; Verzhbitsky et al., 2015), but further work is required to substantiate this interpretation.

The Permian depositional history and sedimentary provenance differ significantly between Severnaya Zemlya, the New Siberian Islands and Wrangel Island. Severnaya Zemlya mainly represented an uplifted area with a few scattered small depressions filled by clastics sourced from adjacent local uplifted blocks (Ershova et al., 2015d), while clastics deposited in both shallow and deep water environments across the New Siberian Islands were sourced from the Uralian Orogen (Ershova et al., 2015b,c). The coeval strata of Wrangel Island were still sourced from the same Caledonian-Baltican provenance as the Carboniferous deposits (Miller et al., 2010), with Uralian signatures only reported from the younger Triassic clastics of Wrangel Island and Chukotka (Miller et al., 2010; Miller et al., 2006). There are a number of paleotectonic models which could be used to interpret the dramatic shift to a Uralian provenance for the Permian clastics of the New Siberian Islands. One potential model involves the eastward translation of the continental block containing the New Siberian Islands, as proposed for Chukotka and Wrangel Island by Miller et al. (2010, 2013). The eastern movement of the continental block containing Wrangel Island and Chukotka was supposedly initiated by Permian-Triassic rifting, subsequently bringing Chukotka and Wrangel Island closer to the Uralian provenance (Miller et al., 2010). A second model involves the transport of clastics from the Uralian Orogen across the vast Barents shelf to the basin located across the present-day New Siberian Islands (Ershova et al., 2015c). The appearance of a Carboniferous-Permian detrital zircons in the Triassic clastics of Wrangel Island and Chukotka (Miller et al., 2010, 2013) could be explained by their more distal location from the Uralian source (possibly along the westernmost margin of the Barents shelf in present-day coordinates) compared to the New Siberian Islands, with progradation of a Uralian-sourced clastic delta system first filling the accommodation across the Barents Shelf and New Siberian Islands during the Permian, before reaching the location of Chukotka and Wrangel Island by the Triassic. Mafic magmatic rocks of latest Permian-earliest Triassic age have been reported within all of these continental terranes, now scattered across the Arctic realm (Kuzmichev and Goldyrev, 2007; Makariev, 2013; Markovsky et al., 1988; Ledneva et al., 2011). The available sparse geochemical data for these magmatic rocks do not give a clear signature of the geodynamic settings under which they formed. Miller et al. (2010) assumed that the Permian-Triassic magmatic rocks represent a rifting event in Chukotka, while Kuzmichev and Goldyrev (2007) argued that the latest Permian-Triassic mafic dykes and sills are similar in composition and age to Triassic Traps on the Siberian Craton.

The Devonian-Permian deposits of northern Siberia generally display a gradational transition from shallow marine to deeper marine environments to the north and east (present-day coordinates), suggesting the presence of an oceanic basin in these directions. Devonian-Lower Carboniferous deposits of Taimyr show a transition from shallow water carbonates to deep water cherts and argillite towards the north, suggesting the presence of a northward deepening passive margin (present-day coordinates). In northeastern Siberia (Lower Lena area), Upper Devonian-lowermost Carboniferous rocks comprise mainly shallow marine carbonates and clastics, with a predicted transition to deeper water deposits further to the east beneath the thrust sheets of the Verkhoyansk FTB, as observed in the younger Paleozoic rocks. The Upper Visean-Permian strata of northeastern Siberia have been interpreted as part of a broad clastic wedge which developed along the length of the eastern passive margin of Siberia (Prokopiev et al., 2001; Ershova et al., 2015a; Khudoley and Prokopiev, 2007; Yapaskurt, 1992). A succession of mainly clastic rocks was deposited across the Taimyr region since the Late Carboniferous, with the infilling of shallow marine basins in the Carboniferous-Early Permian and the development of continental environments by the Middle-Late Permian. A suite of 
provenance studies on the Carboniferous-Permian deposits of northern Siberia have revealed that the main provenance areas were orogens developed along the periphery of the Siberian Craton, with some reworking of the Siberian basement and its overlying sedimentary cover during the Late Carboniferous-Permian (Ershova et al., 2013; Ershova et al., 2015a; Ershova et al., in this issue; Prokopiev et al., 2013; Zhang et al., 2013). Multiple unconformities reported from the Devonian-Carboniferous successions of northern Siberia, along with Central and South Taimyr (Fig. 11), have been tied to eustatic sealevel changes, and were mainly generated along the marginal southern part of the sedimentary basins. Middle-late Paleozoic magmatic activity in northern Siberia is restricted to two different levels, including Late Devonian (Frasnian) rift-related basalts across northeastern Siberia, and Late Permian-earliest Triassic mafic dykes and sills and felsic granitoids. These Late Permian-earliest Triassic intrusives represent the distal magmatic component of the hypothesized mantle plume which generated the vast Siberian Traps centered to the southwest of the study area (Vernikovsky et al., 2003).

Consequently, our overview of sedimentary facies distribution and provenance signals from the Devonian-Permian deposits of the Eastern Russian Arctic reveals a striking similarity between Devonian-Carboniferous strata of Severnaya Zemlya, the New Siberian Islands, Chukotka and Wrangel Island, while northern Siberia appears to have had a significantly different middle-late Paleozoic geological history. The facies distribution within the Devonian-Carboniferous deposits defines a transition from continental to shallow marine depositional environments across Severnaya Zemlya and then from shallow marine to deep marine across the New Siberian Islands, with mainly shallow marine settings across Chukotka. The Devonian-Carboniferous strata from these areas have a very similar distribution of detrital zircon age populations, suggesting a common clastic provenance from the Caledonian Orogeny and possible located along the northern margin of Baltica (present-day coordinates). The Carboniferous-Permian geological history of these regions is much more uncertain due to poor exposure of sediments of this age and/or a lack of available provenance data. We speculate here that the New Siberian Islands, along with Chukotka and Wrangel Island, possibly represented the distal part of the Barents Shelf, while the Kara Terrane (Severnaya Zemlya Archipelago and northern Taimyr) accreted to Siberia in the Carboniferous. To confirm and further refine this model, further provenance studies on the Carboniferous and Permian rocks of Chukotka and Severnaya Zemlya are urgently required, as well as a detailed geochemical study of the Carboniferous-Permian magmatics of the Kara Terrane and Wrangel Island, to provide a better insight into their geodynamic settings.

\section{Acknowledgments}

Reviews by M. Cecile, D. Houseknecht and L. Lane greatly improved the initial manuscript. The research was supported by RFBR grant $15-$ 35-20591, research grant of Saint Petersburg State University 3.38.137.2014, and research program of DMPGI SB RAS VIII.66.1.4, Project 53 (RAS 44P).

\section{Appendix A}

Supplementary data to this article can be found online at http://dx. doi.org/10.1016/j.tecto.2016.03.026.

\section{References}

Abramov, B.S., Grigorieva, A.D., 1983. Biostratigraphy and Brachiopods of the Middle and Upper Carboniferous Deposits of Verkhoyansk Region. Nauka, Moscow (in Russian).

Abramov, B.S., Grigorieva, A.D., 1986. Biostratigraphy and Brachiopods of the Lower Carboniferous Deposits of Verkhoyansk Region. Nauka, Moscow (in Russian).

Amato, J.M., Aleinikoff, J.N., Akinin, V.V., McClelland, W.C., Toro, J., 2014. Age, chemistry, and correlations of Neoproterozoic-Devonian igneous rocks of the Arctic AlaskaChukotka terrane: an overview with new U-Pb ages. Spec. Pap. Geol. Soc. Am. 506, 29-57.
Bondarenko, S.A., Vinogradov, V.A., Goryachev, Yu.V., Gusev, E.A, Zayonchek, A.V., Kiyko, O.A., Lopatin, B.G., Opekuno, A.Yu., Romashchenko, O.G, Suprunenko, O.I, Sukhov, K.S., Usov, A.N., Chernykh, A.A., 2014. Geological Map of the Russia, Scale 1: 1,000,000, Quadrangles R1, 2. Kartfabrika VSEGEI, Saint Petersburg (in Russian).

Budnikova, I.V., Budnikov, V.M., Grausman, V.V., Danilov, V.I., Mikhailova, T.E., 1991. Lithostratigraphy of the Middle Paleozoic of marginal basins in the northeastern Siberian platform. Stratigraphy and Lithofacies Analysis of the Upper Paleozoic of Siberia. Nauka, Novosibirsk, pp. 5-13 (in Russian).

Bulgakova, M.D., 1967. Krestyah conglomerates of the Lena R. Delta and the conditions of their formation. Lithol. Miner. Resour. 3, 127-134 (in Russian).

Cecile, M.P., Lane, L.S., Kos'ko, M.K., Bychkov, Yu.M., Begunov, S.F., Gorodinsky, M.E., Paraketsov, C.V Paraketsova, G.J., Vinogradova, O.N., Yegonov, A.A. 1991. Report on the joint visit of Canadian and Soviet scientists to the northeastern Soviet Union. Episodes $14,125-130$.

Cherkesova, S.V., 1972. Comparative characteristic lower-middle Devonian deposits northwest part of Kotel'ny Island with other Arctic regions. In: Volnov, D.A., Ivanova, V.L. (Eds.), Geology and Mineral Resources of New Siberian Islands and Wrangel Island, Leningrad, pp. 22-27 (in Russian).

Colpron, M., Nelson, J.L., 2011. A Paleozoic NW passage and the Timanian, Caledonian and Uralian connections of some exotic terranes in the North American Cordillera. In: Spencer, A.M., Embry, A.F., Gautier, D.L., Stoupakova, A.V., Sorensen, K. (Eds.), Arctic Petroleum Geology. Geological Society Memoir 35, pp. 463-484.

Danukalova, M.K., Kuzmichev, A.B., Aristov, V.A., 2014. Upper Devonian depositional system of Bel'kov Island (New Siberian Islands): an intracontinental rift or a continental margin? Geotectonics 48 (5), 390-412.

Dibner, A.F., 1982a. The age of clastic sediments of the Carboniferous and Permian deposits of Severnaya Zemlya Archipelago based on palynological data. In: Kabankov, V.Ya, Lazarenko, N.P. (Eds.), Geology of Severnaya Zemlya Archipelago, pp. 124-129 (in Russian).

Dibner, A.F., 1982b. Palynological proof of the presence of Carboniferous and Permian deposits in Soviet Arctic islands. In: Dibner, A.F. (Ed.), Microfossils of the Polar Regions and their Stratigraphic Significance, pp. 63-73 (in Russian).

Dumoulin, J.A., Harris, A.G., Gagiev, M., Bradley, D.C., Repetski, J.E., 2002. Lithostratigraphic, conodont, and other faunal links between lower Paleozoic strata in northern and central Alaska and northeastern Russia. Spec. Pap. Geol. Soc. Am. 360, 291-312.

Egorov, A.Yu., 1993. The avalanche sedimentation - the main process in the formation of the Verkhoyansk complex. Dokl. Earth Sci. 332 (3), 346-351 (in Russian).

Egorov, A.Yu, Andreev, V.S., 1981. Permian deposits of northern Verkhoyanye. Izvestiya Academy of Sciences USSR. Ser. Geol. 3, 72-81 (in Russian).

Ershova, V.B., Khudoley, A.K., Prokopiev, A.V., Fefilova, L.A., 2012. Deposits in paleokarst caverns as indicators of Carboniferous paleogeographic environments in the northeastern part of the Siberian platform. Dokl. Earth Sci. 442 (2), 168-172.

Ershova, V.B., Khudoley, A.K., Prokopiev, A.V., Tuchkova, M.I., Fedorov, P.V., Kazakova, G.G. Shishlov, S.S., O'Sullivan, P., 2016a. Trans-Siberian Permian Rivers: A Key to Understanding Arctic Sedimentary Provenance (in this issue)

Ershova, V.B., Lorenz, H., Prokopiev, A.V., Sobolev, N.N., Khudoley, A.K., Petrov, E.O., Estrada, S., Sergeev, S., Larionov, A., Thomsen, T.B., 2016b. The De Long Islands: a missing link in unraveling the Paleozoic paleogeography of the Arctic. Gondwana Res. http://dx.doi.org/10.1016/j.gr.2015.05.016 (in press).

Ershova, V.B., Prokopiev, A.V., Khudoley, A.K., 2015d. Integrated provenance analysis of Carboniferous deposits from northeastern Siberia: implication for the Late Paleozoic history of the Arctic. J. Asia Earth Sci. 109, 38-49.

Ershova, V.B., Prokopiev, A.V., Khudoley, A.K., Sobolev, N.N., Petrov, E.O., 2015a. Detrital zircon ages and provenance of the Upper Paleozoic successions of Kotel'ny Island (New Siberian Islands Archipelago). Lithosphere 7, 40-45.

Ershova, V.B., Prokopiev, A.V., Khudoley, A.K., Sobolev, N.N., Petrov, E.O., 2015b. U/Pb dating of detrital zircons from Upper Paleozoic deposits of Bel'kovsky Island (New Siberian Islands): critical testing of Arctic tectonic models. Int. Geol. Rev. 57 (2), 199-210.

Ershova, V.B., Prokopiev, A.V., Nikishin, V.A., Khudoley, A.K., Nikishin, A.M., 2015c. New data on Upper Carboniferous Lower Permian deposits of Bol'shevik Island, Severnaya Zemlya Archipelago. Polar Res. http://dx.doi.org/10.3402/polar.v34.24558.

Ershova, V.B., Khudoley, A.K., Prokopiev, A.V., 2013. Reconstruction of provenances and Carboniferous tectonic events in the North-East Siberian Craton framework according to U-Pb dating of detrital zircons. Geotectonics 47 (2), 93-100.

Ershova, V.B., Khudoley, A.K., Prokopiev, A.V., 2014. Early Visean paleogeography of northern Siberia: new evidence of rift to drift transition along the eastern margin of Siberia. J. Asia Earth Sci. 91, 206-217.

Gaiduk, V.V., 1988. Vilyui Middle Paleozoic Rift System. Yakutian branch of Academy of Sciences of the USSR, Yakutsk (128 pp.,in Russian).

Gogina, N.I, 1979. State Geological Map of the USSR. Scale 1:200,000. Sheet S-52-XXXI, XXXII. Series - Lower Lena. Explanatory note. Moscow. (in Russian)

Gramberg, I.S., Ushakov, V.I. (Eds.), 2000. Severnaya Zemlya-Geology and Mineral Resources. VNIIOkeangeologia, St. Petersburg (in Russian).

Ivanov, O.N., 1973. Stratigraphy of Wrangel Island. Isv. Akad. Nauk SSSR Geol. Ser. 5, 104-115 (in Russian).

Kalinko, M.K., 1953. Geology and Petroleum Potential of the Peninsula Nordvik (YurungTumus). Glavsevmorput, Leningrad (in Russian).

Kameneva, G.I., Chernyak, G.E., 1975. Kamennougol'nye I Permskie Otlozhniya Ostrova Wrangelya, in: Verkhnii Paleozoi Severo-Vostoka, SSSR. Nauchno-Issledovtel'skii Institut Geologii Artiki, Leningrad, pp. 76-79 (in Russian).

Katkov, S.M., Luchitskaya, M.V., Kotov, A.B., Sal'nikova, E.B., Yakovleva, S.Z., 2013. Late Paleozoic granitoids of Central Chukotka: structural position and age constraints. Dokl. Earth Sci. 450 (1), 484-488.

Khanin, A.F., 1982. Stratigraphy of Devonian deposits of Severnaya Zemlya. In: Kabankov, V. Ya, lazarenko, N.P. (Eds.), Geology of Severnaya Zemlya Archipelago, pp. 103-119 (in Russian). 
Khudoley, A.K., Guriev, G.A., 2003. Influence of syn-sedimentary faults on orogenic structure: examples from the Neoproterozoic-Mesozoic east Siberian passive margin. Tectonophysics 365, 23-43.

Khudoley, A.K., Prokopiev, A.V., 2007. Defining the eastern boundary of the North Asian Craton from structural and subsidence history studies of the Verkhoyansk fold and thrust belt. In: Sears, J., Harms, T., Evenchick, C. (Eds.), Whence the Mountains? Enquiries into the Evolution of Orogenic Belts: A Volume in Honor of Raymond A. Price. The Geological Society of America Special Paper Vol. 433, pp. 391-410.

Kontorovich, V.A., Kontorovich, A.E., Gubin, I.A., Zoteev, A.M., Lapkovsky, V.V., Malyshev, N.A., Soloviev, M.V., Fradkin, G.S., 2013. The Neoproterozoic-Phanerozoic section of the Anabar-Lena province: structural framework, geological model, and petroleum potential. Russ. Geol. Geophys. 54 (8), 1253-1274.

Kos'ko, M., Korago, E., 2009. Review of geology of the New Siberian Islands between the Laptev and the east Siberian seas, North East Russia. Stephan Mueller Spec. Publ. Ser. 4, 45-64.

Kos'ko, M.K., Avdyunichev, V.V., Ganelin, V.G., Opeskunov, A.Yu, Opeslunova, M.G., Cecile, M.P., Smirnov, A.N., Ushakov, V.I., Khandozhko, N.V., Harrison, J.C., Shul'ga, D.Yu., 2003. The Wrangel Island: Geological Structure, Mineragenesis, Environmental Geology. VNIIOkeangeologia, Saint Petersburg (in Russian)

Kos'ko, M.K., Bondarenko, N.S., Nepomiluev, V. F., 1985. State Geological Map of the USSR, Scale 1:200,000 (New Siberian Islands), Quadrangles T-54-XXXI, XXXII, XXXIII; S-53IV, V, VI; S-54-I, II, III, S-54-VII, VIII, IX, XIII, XIV, XV, Explanatory Note. "Sevmorgeologia", Leningrad (in Russian).

Kos'ko, M.K., Cecile, M.P., Harrison, J.C., Ganelin, V.G., Khandoshko, N.V., Lopatin, B.G., 1993. Geology of Wrangel Island, between Chukchi and east Siberian seas, northeastern Russia. Geol. Surv. Can. Bull. 461, 101.

Kos'ko, M.K., Lopatin, B.G., Ganelin, V.G., 1990. Major geological features of the islands of the east Siberian and Chukchi seas and northern coast of Chukotka. Mar. Geol. 93, 349-367.

Kos'ko, M.K., Sobolev, N.N., Korago, E.A., Proskurnin, V.F., Stolbov, N.M., 2013. Geology of New Siberian Islands-a basis for interpretation of geophysical data on the eastern Arctic shelf of Russia. Neftegazovaya Geologiya. Teor. Pract. 8 (2), 1-36 (in Russian).

Kos'ko, M.K., Sobolevskaya, R.F., Nepomiluev, V.F., Volnov, D.A., 1972. Cambrian-Middle Devonian deposits of New Siberian Islands. In: Volnov, D.A., Ivanova, V.L. (Eds.), Geology and Mineral Resources of New Siberian Islands and Wrangel Island, Leningrad, pp. 8-21 (in Russian).

Kuzmichev, A.B., Goldyrev, A.E., 2007. Permian-Triassic trap magmatism in Bel'kov Island (New Siberian Islands). Russ. Geol. Geophys. 48 (2), 167-176.

Lane, L.S., Cecile, M.P., Gehrels, G.E., Kos'ko, M.K., Layer, P.W., Parrish, R.R., 2015. Geochronology and structural setting of Latest Devonian-Early Carboniferous magmatic rocks, Cape Kiber, northeast Russia. Can. J. Earth Sci. 52, 147-160. http://dx.doi.org/ $10.1139 /$ cjes20130184.

Ledneva, G.V., Pease, V.L., Sokolov, S.D., 2011. Permo-Triassic hypabyssal mafic intrusions and associated tholeiitic basalts of the Kolyuchinskaya Bay, Chukotka (NE Russia): links to the Siberian LIP. J. Asian Earth Sci. 40, 737-745.

Lorenz, H., Gee, D.G., Simonetti, A., 2008a. Detrital zircon ages and provenance of the late Neoproterozoic and Palaeozoic successions on Severnaya Zemlya, Kara Shelf: a tie to Baltica. Nor. J. Geol. 88 (4), 235-258.

Lorenz, H., Gee, D.G., Whitehous, M., 2007. New geochronological data on Palaeozoic igneous activity and deformation in the Severnaya Zemlya Archipelago, Russia, and implications for the development of the Eurasian Arctic margin. Geol. Mag. 144, 105-125.

Lorenz, H., Männik, P., Gee, D., Proskurnin, V., 2008b. Geology of the Severnaya Zemlya Archipelago and the North Kara Terrane in the Russian high Arctic. Int. J. Earth Sci. (Geol. Rundsch.) 97, 519-547.

Luchitskaya, M.V., Sokolov, S.D., Kotov, A.B., Natapov, L.M., Belousova, E.A., Katkov, S.M., 2015. Late Paleozoic granitic rocks of the Chukchi Peninsula: composition and location in the structure of the Russian Arctic. Geotectonics 49 (4), 243-268.

Makariev, A.A. (Ed.), 2013. State Geological Map of the Russian Federation. Scale 1: $1,000,000$ (Third Generation). Sheet T-45 - 48th. Cheliuskin. Explanatory Note. VSEGEI Publishing House, St. Petersburg (in Russian).

Markovsky, V.A., Kulyasheva, L.N., 1993. State Geological Map of the Russian Federation. Scale 1:200,000. Sheet U-46-XXVIII, XXIX, XXX. VSEGEI. Saint Petersburg.

Markovsky, V.A., Kulyasheva, L., N., Makariev, A.A., 1984. State Geological Map of the Russian Federation. Scale 1:200,000. Sheet T-47-I, II, III, IV, V. VSEGEI Publishing House, Leningrad. (in Russian)

Markovsky, V.A., Paderin, P.G., Shneider, G.B., Lazareva, L.N., Kuz'min, V.G., Lazurenko, V.I., 1988. State Geological Map of the Russian Federation. Scale 1:200,000. Sheet T-47-VI, XI, XII; T-48-I, VII, VIII, IX, X; T-47-XVI, XVII, XVIII, XXII, XXIII; T-48-XIII, XIV, XV, XVI, XVII, XVIII (Bol'shevik Island). VSEGEI Publishing House, St. Petersburg. (in Russian)

Matukhin, R.G., 1991. Devonian and Lower Carboniferous of the Siberian Platform. Nauka Publishing House, Novosibirsk (191 pp. in Russian).

Matukhin, R.G., Menner, V.V. (Eds.), 1999. Stratigraphy Silurian and Devonian Strata of Severnaya Zemlya. SNIIGIMS Publishing House, Novosibirsk (174 pp., in Russian).

Matukhin, R.G., Menner, V.V., Sokolov, P.N., Reshetnyak, D.R., 1995. Devonian Stratigraphic Base of the Siberian Platform (Novosibirsk, 82 pp. in Russian).

Menner, V.V., Sidyachenko, A.I., 1975. Upper Devonian of the lower reaches of the river Lena. Dokl. AN SSSR 220 (1), 178-181 (in Russian).

Menner, V.V. Smirnova, M.A., Cherkesova, S.V., 1982. Composition and age of Rusanovskaya Formation (Severnaya Zemlya Archipelago). In: Kabankov, V.Ya, Lazarenko, N.P. (Eds.), Geology of Severnaya Zemlya Archipelago, pp. 120-123 (in Russian).

Metelkin, D.V., Vernikovsky, V.A., Kazansky, A.Yu., Bogolepova, O.K., Gubanov, A.P., 2005 Paleozoic history of the Kara microcontinent and its relation to Siberia and Baltica: paleomagnetism, paleogeography and tectonics. Tectonophysics 398, 225-243.

Metelkin, D.V., Vernikovsky, V.A., Matushkin, N.Yu., Tolmacheva, T.Yu., Zhdanova, A.I., 2014. First paleomagnetic data for the Early Paleozoic deposits of New Siberian
Islands: concerning the formation of the South Anyui Suture and tectonic reconstruction of Arctida. Litosfera 3, 11-31 (in Russian).

Mezhvilk, A.A., Markov, F.G. 1983. State Geological Map of the Russian Federation. Scale 1: $1,000,000$. Sheet R-50-52. Explanatory Note. VSEGEI Publishing House, Leningrad. (in Russian)

Miller, E.L., Verzhbitsky, V., 2009. Structural studies in the Pevek region, Russia: implications for the evolution of the east Siberian shelf and Makarov Basin of the Arctic Ocean. In: Stone, D.B. (Ed.), Origin of Northeastern Russia: Geology, Tectonics and PaleomagStephan Mueller Publication Series. European Geophysical Union, pp. 223-241.

Miller, E.L., Gehrels, G.E., Pease, V., Sokolov, S., 2010. Stratigraphy and U-Pb detrital zircon geochronology of Wrangel Island, Russia: implications for Arctic paleogeography. Am. Assoc. Pet. Geol. Bull. 94, 665-692.

Miller, E.L., Soloviev, A.V., Prokopiev, A.V., Toro, J., Harris, D., Kuzmichev, A.B., Gehrels, G.E. 2013. Triassic river systems and the paleo-Pacific margin of northwestern Pangea. Gondwana Res. 23 (4), 1631-1645.

Miller, E.L., Toro, J., Gehrels, G.E., Amato, J.M., Prokopiev, A., Tuchkova, M.I., Akinin, V.V. Dumitru, T.A., Moore, T.E., Cecile, M.P., 2006. New insights into Arctic paleogeography and tectonics from U-Pb detrital zircon geochronology. Tectonics 25 (TC3013). http://dx.doi.org/10.1029/2005TC001830 (19 pp.).

Natal'in, B.A., Amato, J.M., Toro, J., Wright, J.E., 1999. Paleozoic rocks of northern Chukotka Peninsula, Russian Far East: implications for the tectonics of the Arctic region. Tectonics 18 (6), 977-1003.

Nikolaeva, S.V., Kuzmichev, A.B., Aristov, V.A., 2009. On Frasnian ammonoids of the New Siberian Islands. Paleontol. J. 43 (2), 134-141.

Parfenov, L.M., 1984. Continental Margins and Island Arcs of Northeastern Asian Mesozoides. Nauka, Novosibirsk (in Russian).

Parfenov, L.M., 1991. Tectonics of the Verkhoyansk-Kolyma Mesozoides in the context of plate tectonics. Tectonophysics 139, 319-342.

Parfenov, L.M., Berzin, N.A., Khanchuk, A.I., Badarch, G., Belichenko, V.G., Bulgatov, A.N. Dril', S.I., Kirillova, G.L., Kuz'min, M.I., Nokleberg, W., Prokopiev, A.V., Timofeev, V.F., Tomurtogoo, O., Yan, H., 2003. Model for the formation of orogenic belts of central and northeast Asia. Tikhookean. Geol. 6, 7-42 (in Russian).

Pease, V.L., Kuzmichev, A.B., Danukalova, M.K., 2015. The New Siberian Islands and evidence for the continuation of the Uralides, Arctic Russia. J. Geol. Soc. 172 (1), 1-4.

Pogrebitskiy, Yu.E, Lopatin, B.G.,1999a. State Geological Map of the Russian Federation. Scale 1:1,000,000. S-44-46., Explanatory Note. VSEGEI Publishing House, St. Petersburg. (in Russian)

Pogrebitskiy, Yu.E, Lopatin, B.G., 1999b. State Geological Map of the Russian Federation. Scale 1:1,000,000. Quadrangles S-44-46. Explanatory Note. VSEGEI Publishing House, St. Petersburg. (in Russian)

Pogrebitskiy, Yu.E., Shanurenko, N.K., 1998a. State Geological Map of the Russian Federation. Scale 1:1,000,000. Sheet S-47-49. Explanatory Note. VSEGEI Publishing House, St. Petersburg. (in Russian)

Pogrebitskiy, Yu.E., Shanurenko, N.K., 1998b. State Geological Map of the Russian Federation. Scale 1:1,000,000. Sheet S-47-49. Explanatory Note. VSEGEI Publishing House, St. Petersburg. (in Russian)

Prokopiev, A., Ershova, V, Anfinson, O., Khudoley, A., Vasiliev, D., Stockli, D., 2015. Tectonics of New Siberia Islands: structural styles and zircon U-Th/He ages. Abstracts of 7th International Conference on Arctic Margins (ICAM VII) (M. Smelror, Ed.), Trondheim, Norway, Geological Survey of Norway, Report No.: 2015.032, ISSN: 2387-3515 (Online), $120-121$.

Prokopiev, A.V., Ershova, V.B., Miller, E.L., Khudoley, A.K., 2013. Early Carboniferous paleogeography of the northern Verkhoyansk passive margin as derived from $\mathrm{U}-\mathrm{Pb}$ dating of detrital zircons: role of erosion products of the Central Asian and TaimyrSevernaya Zemlya fold belts. Russ. Geol. Geophys. 54 (10), 1195-1204.

Prokopiev, A.V., Parfenov, L.M., Tomshin, M.D., Kolodeznikov, I.I., 2001. Sedimentary cover of the Siberian platform and adjacent fold-and-thrust belts. In: Parfenov, L.M. Kuzmin, M.I. (Eds.), Tectonics, Geodynamics and Metallogeny of the Territory of the Sakha Republic (Yakutia). MAIK “Nauka/Interperiodika”, Moscow, pp. 113-155 (in Russian).

Proskurnin, V.F., Gavrish A.V., Mezhubovsky, V.V., Trofimov, V. R. et al., 2013. State Geological Map of the Russian Federation. Scale 1:1,000,000 (Third Generation). Series Taimyr-Severnaya. Sheet S-49 - Khatanga Bay. Explanatory Note. Cartographic Factory, St. Petersburg. (in Russian)

Rogozov, Yu.G., Vasilieva, H.M., 1968. Devonian strata of coastal deposit of Long Strait Uchenye zapiski NIIGA 18, 151-157 (in Russian).

Samorukov, N.M., Matvienko, V.T., 1984. Geological Map of the USSR, Scale 1:200,000 Quadrangles R59-XXIII, XXIV, Severo-Vostochnoe proizvodstvennoe geologicheskoe ob'edinenie, Moscow. (in Russian)

Samusin, A.I., Belousov, K.N., 1985. State Geological Map of the USSR, Scale 1:200,000 (New Siberian Islands), Quadrangles S-53-XVI, XVII, XXII, XXIII; S-54-XIV, XV, XVI; S-54-XX, XXI, XXII; S-54-XXIII, XXIV; S-54-XXVII, XXVIII; S-54-XXIX, XXX, Explanatory Note. Moscow. (in Russian)

Shaposhnikov, G.N., Aleksandrova, T.P., Ganeshin, G.S., Egorov, S.V., Il'in, K.B., Stralnikova S.I., 1999. Geological Map of the Russia, Scale 1:1000,000, Quadrangles R 58(60) Kartfabrika VSEGEI, Saint Petersburg. (in Russian)

Shishlov, S.B., Onishenko, A.N., Megubovskiy, V.V., 1997. Stratigraphy and zonation of Upper Paleozoic terrigeneous formation of Taimyr Peninsula. In: Simonov, O.N (Ed.), Bowels of Taimyr. 2, pp. 60-72 (in Russian).

Smetannikova, L.I., Grinenko, V.S., Malanin, Yu.A., Prokopiev, A.V., Knyazev, V.G., Trushchelev, A.M., Yuganova, L.A., Zharikova L.P., Kazakova, G.G., Shepelev, N.G. Yagnyshev B.S., 2013. State Geological Map of the Russian Federation. Scale 1: 1,000,000 (third generation). Quadrangles R-51. Dzhardzhan. Explanatory Note. VSEGEI Publishing House, St. Petersburg. (in Russian) 
Sobolev, N.N., 1997. Stratigraphy of Devonian strata of Taimyr. In: Simonov, O.N. (Ed.), Bowels of Taimyr. 2, pp. 45-59 (in Russian).

Sobolev, N.N., 1999. Stratigraphy of Lower Carboniferous strata of Taimyr. In: Simonov, O.N. (Ed.), Bowels of Taimyr. 3, pp. 11-21 (in Russian).

Sobolev, N.N., Engalychev, S.Y., Leontiev, D.I., Proskurnin, V.F., 2013. Guide of expedition to Severnaya Zemlya Archipelago. On the 100th Anniversary of the Opening Severnaya Zemlya Archipelago. VSEGEI Publishing House, St. Petersburg (in Russian)

Sokolov, S.D., Ledneva, G.V., Tuchkova, M.I, Luchitskaya, M.V., Ganelin, A.V., Verzhbitsky, V.E., 2014. Chukchi Arctic continental margins: tectonic evolution, link to the opening of the Amerasia Basin. ICAM VI Proceedings of the International Conference on Arctic Margins VI, Fairbanks, Alaska, May 2011. Press VSEGEI, Saint Petersburg, pp. 97-113.

Solomina, R.V., 1997. Permian biostratigraphic scheme of Verkhoyanye. Otechestv. Geol. 3, 37-43 (in Russian).

Tuchkova, M.I., Sokolov, S.D., Khudoley, A.K., Verzhbitsky, V.E., Hayasaka, Y., Moiseev, A.V., 2014. Permian and Triassic deposits of Siberian and Chukotka passive margins: sedimentation setting and provenances. ICAM VI Proceedings of the International Conference on Arctic Margins VI, Fairbanks, Alaska, May 2011. Press VSEGEI, Saint Petersburg, pp. 61-96.

Vanin, A.L., Galabala, R.O., Krutiy, G.V., Nabatova, L.N., Treshalov, A.V, 2001. State Geological Map of the Russian Federation. Scale 1:1,000,000. Sheet S-50-52-Bykovskiy. Explanatory Note. Cartographic Factory, St. Petersburg. (in Russian)
Vasil'eva, N.M., Solovieva, M.F., 1979. Stratigraphy of Carboniferous rocks of Chukotka and Wrangel Island. VIII International Congress on Carboniferous Stratigraphy and Geology 2. Nauka, Moscow, pp. 105-111 (in Russian).

Vernikovsky, V.A., Pease, V.L., Vernikovskaya, A.E., Romanov, A.P., Gee, D.G., Travin, A.V., 2003. First report of early Triassic A-type granite and syenite intrusions from Taimyr: product of the northern Eurasian superplume? Lithos 66 (1-2), 23-36.

Verzhbitsky, V.E., Sokolov, S.D., Tuchkova, M.I., 2015. Present-day structure and stages of tectonic evolution of Wrangel Island, Russian Eastern Arctic Region. Geotectonics 49 (3), 165-192

Vladimirtseva, Yu.A, Dykanuk, E.A., Manukyan, A.M., Stepina, T.S., Surmilova, E.P., 2001. Geological Map of the Russia, Scale 1:1,000,000, Quadrangle Q2. Kartfabrika VSEGEI, Saint Petersburg. (in Russian)

Yapaskurt, O.V., 1992. Lithogenesis and Mineral Deposits of Miogeosynclines. Nedra Publishing house, Moscow (152 pp., in Russian).

Yazikov, A., Izokh, N.G., Saraev, S.V., Bakharev, N.K., Gonta, T.V., Sobolev, E.S., 2013. New data on the upper Devonian biostratigraphy and sedimentology of Stolb Island (Lena River delta). Russ. Geol. Geophys. 54 (8), 780-791.

Zhang, X., Omma, J., Pease, V., Scott, R., 2013. Provenance of Late Paleozoic-Mesozoic sandstone, Taimyr Peninsula, the Arctic. Geosci. (Switzerland) 3 (3), 502-527.

Zonenshain, L.P., Kuz'min, M.I., Natapov, L.M., 1990. Geology of the USSR: A Plate-Tectonic Synthesis. Geodynamics Series 21. American Geophysical Union, Washington. 